\title{
Impact of Forage Fertilization with Urea and Composted Cattle Manure on Soil Fertility in Sandy Soils of South-Central Vietnam
}

\author{
Keenan C. McRoberts, ${ }^{1}$ Quirine M. Ketterings, ${ }^{2}$ David Parsons, ${ }^{3}$ Tran Thanh Hai, \\ Nguyen Hai Quan, ${ }^{4}$ Nguyen Xuan Ba, ${ }^{4}$ Charles F. Nicholson, ${ }^{5}$ and Debbie J. R. Cherney ${ }^{6}$ \\ ${ }^{1}$ Department of Animal Science, Cornell University, 149 Morrison Hall, Ithaca, NY 14853, USA \\ ${ }^{2}$ Department of Animal Science, Cornell Nutrient Management Spear Program, Cornell University, \\ 323 Morrison Hall, Ithaca, NY 14853, USA \\ ${ }^{3}$ School of Land and Food, University of Tasmania, Private Bag 98, Hobart, TAS 7001, Australia \\ ${ }^{4}$ Hue University of Agriculture and Forestry, 102 Phung Hung Street, Hue, Vietnam \\ ${ }^{5}$ Department of Supply Chain and Information Systems, The Pennsylvania State University, \\ 467 Business Building, University Park, PA 16802, USA \\ ${ }^{6}$ Department of Animal Science, Cornell University, 329 Morrison Hall, Ithaca, NY 14853, USA \\ Correspondence should be addressed to Keenan C. McRoberts; kcm45@cornell.edu
}

Received 1 November 2015; Accepted 20 January 2016

Academic Editor: Glaciela Kaschuk

Copyright (C) 2016 Keenan C. McRoberts et al. This is an open access article distributed under the Creative Commons Attribution License, which permits unrestricted use, distribution, and reproduction in any medium, provided the original work is properly cited.

Increased production in smallholder beef systems requires improved forage management. Our objective was to evaluate the effects of composted cattle manure and mineral nitrogen (urea) application on soil fertility and partial nutrient balances in plots established to Brachiaria cv. Mulato II in south-central coastal Vietnam from 2010 to 2013. A randomized complete block design was implemented on six farms (blocks), with five rates of composted cattle manure $(0,4,8,12$, and $24 \mathrm{Mg} \mathrm{DM} / \mathrm{ha}$ per yr) and three urea rates $(0,60$, and $120 \mathrm{~kg} \mathrm{~N} /$ ha per yr) in a factorial design. Soil was analyzed before and after the experiment. Compost increased soil $\mathrm{pH}$, organic matter, $\mathrm{Ca}, \mathrm{Mg}$, and $\mathrm{Mn}$. The effect of compost and urea applications on postexperiment soil fertility depended on preexperiment soil fertility for $\mathrm{K}, \mathrm{P}, \mathrm{S}, \mathrm{Mg}, \mathrm{Zn}, \mathrm{Mn}, \mathrm{Cu}$, and organic matter, suggesting that the ability to maintain soil fertility depends on the interaction between soil organic and inorganic amendments and existing soil fertility. Highest farm yields were also achieved on farms with higher preexperiment soil fertility levels. Negative partial nutrient balances for N, P, and K suggest that yields will not be sustainable over time even for the highest fertilization inputs used in this experiment.

\section{Introduction}

Smallholder crop-livestock farms ( $\leq 5$ head of cattle/household) in south-central coastal Vietnam contribute to beef supply for urban areas [1]. Semi-intensive (grazing and stall feeding) and extensive (grazing of communal land) cattle management systems are dominant in the region. Supplementary stall feeding, with a basal diet of rice straw, peanut straw, and cultivated forage (e.g., Pennisetum purpureum) or cut-and-carry native grasses and legumes from private and communal land, complements supervised or unsupervised grazing on communal (and private) lands [1]. Progressive farmers have transitioned toward semi-intensive management of backyard plots to increase animal productivity (daily gain) using supplementary forages (native grasses and legumes and cultivated improved forages) and concentrates and reducing energy expenditures incurred from walking to open grazing areas. Key to this transition is cultivation of high-yielding, high nutritive value forages that are well adapted to local climatic and soil conditions [1-4]. Farmers 
also benefit from reduced labor requirements for cattle production when forages are cultivated near the household $[3,5]$.

Adoption of Brachiaria spp. grasses in tropical Latin America has been important to productivity and economic gains in dairy and beef systems [6] and can be managed under grazing or cut-and-carry systems. Similar benefits are emerging in smallholder crop-livestock systems in Vietnam and other southeast Asian countries due to adoption of Brachiaria spp. hybrids such as Mulato (B. brizantha $\times$ B. ruziziensis) and Mulato II (B. ruziziensis $\times$ B. decumbens $\times$ B. brizantha) and other improved forages [2, 4, 7]. Brachiaria spp. hybrids are popular among farmers in Vietnam due to high palatability, high leaf to stem ratios, easy establishment, and good yield potential relative to other forages [2, 4].

Sandy soils in Vietnam, similar to other tropical systems, pose a unique set of fertility constraints [8], including nutrient deficiencies and low soil organic matter (OM) concentrations [9]. Low organic matter contributes to low cation exchange capacity (CEC), low water holding capacity, and high potential nutrient losses due to runoff, leaching, volatilization, and denitrification. Data supporting forage management decisions in sandy, tropical, rain-fed systems such as those located in the south-central Vietnam coast are inadequate $[7,10]$. Vietnamese farmers identify fertilization management of forages as a critical decision impacting productivity and soil fertility over time. Palm et al. [11], Zingore et al. [12], Goyal et al. [13], and Kaur et al. [14] suggest that a combination of locally available organic nutrient sources and fertilizer might be needed to enhance productivity in the tropics. Farmers in south-central coastal Vietnam typically use composted cattle manure combined with occasional inorganic fertilizer applications (urea and/or NPK blends) and generally follow a "more is better" approach to composted manure applications based on plant color and vigor.

The objective of this study was to assess the effects of urea and composted cattle manure on soil fertility and partial nutrient balances in a multiyear $(29 \mathrm{mo})$ on-farm field experiment. We report on soil fertility and nutrient balances under various nutrient management scenarios.

\section{Methods}

2.1. Cát Trinh Commune Characteristics. The experiment was undertaken from 2010 to 2013 in Cát Trinh Commune, Phù Cát District, Bình Định Province in southcentral coastal Vietnam. The district capital of Ngô Mây $\left(14^{\circ} 0^{\prime} 2^{\prime \prime} \mathrm{N}, 109^{\circ} 2^{\prime} 38^{\prime \prime} \mathrm{E}\right)$ borders Cát Trinh Commune to the southwest. Sandy soils in the commune belong to the Arenosols Group [21]. Annual rainfall in the region is about $1,200 \mathrm{~mm}$, with over $70 \%$ falling during the rainy season (September to December). The range in average monthly temperature is from 23 to $31^{\circ} \mathrm{C}$. Farms were selected in regions where the Australian Centre for International Agricultural Research-funded Project SMCN/2007/109, entitled "Sustainable and Profitable Crop and Livestock Systems for South-Central Coastal Vietnam," was taking place. Project presence simplified access to commune farms (including permission requirements with local and regional authorities) and permitted adequate experiment tracking due to partnerships with rural development professionals and extension educators operating in the commune. This experiment responded directly to problems identified by local farmers and revealed during baseline project surveys $[1,22]$.

\subsection{Farm Selection and Experiment Preparation. Recent field} histories for the six farms participating in the experiment included (1) Pennisetum purpureum Schumach. cultivation, (2) vacant with household waste and ash accumulation, (3) cassava and eggplant production, (4) cassava production, (5) peanut production, and (6) vacant lot. A range of backyard sandy soils in Vietnam and potentially in other tropical regions were represented in initial soil fertility conditions (Table 1). Preexperiment (2010) soil samples at a depth of 15 to $25 \mathrm{~cm}$ indicated low organic matter, low nutrient concentrations, and acidic soils (Table 1). Soil textural classes consisted of sands and loamy sands with very low cation exchange capacity (Table 1).

Experimental areas were prepared using animal traction and handheld hoes in July 2010 according to farmer practice. Weeding was done using handheld hoes as needed throughout the experiment (typically one to two times per month). A woven wire fence (1.2 $\mathrm{m}$ high) was installed around each area to inhibit animal entry. No pesticides were applied during the experiment.

Starter fertilizer (20-20-15; N- $\left.\mathrm{P}_{2} \mathrm{O}_{5}-\mathrm{K}_{2} \mathrm{O}\right)$ was applied at $175 \mathrm{~kg} /$ ha before transplanting Brachiaria cV. Mulato II (B. ruziziensis $\times B$. decumbens $\times B$. brizantha) seedlings into experimental plots in September 2010 and a second time after transplanting in October 2010. Mulato II plant establishment density in each $2 \times 2 \mathrm{~m}$ plot was 20 plants, derived from $50 \mathrm{~cm}$ row spacing and $40 \mathrm{~cm}$ plant spacing. Replanting was completed during the first two months after establishment (September and October 2010) to obtain desired density (50,000 plants/ha). One-meter buffer strips and outer borders separated plots and contained single row of Mulato II with $40 \mathrm{~cm}$ spacing between plants.

2.3. Composted Cattle Manure Treatment Preparation, Sampling, and Analyses. Preexperiment compost samples contained $50 \% \mathrm{DM}$ and $1 \mathrm{~g} / \mathrm{kg} \mathrm{N}$, which were used to define treatment application rates. Farmer practice in the region dictated compost preparation. Experimental compost treatments were supplied entirely by farm 3 to ensure consistent composition. Compost preparation included daily removal of cattle manure and rice straw refusals from cattle pens into an uncovered pile. Compost was turned at least twice prior to use during the approximately $45 \mathrm{~d}$ process. Experimental treatment composition was determined by collecting three representative subsamples ( $150 \mathrm{~g}$ each) of the composted cattle manure during each treatment application period (Table 2). The subsamples were dried to stable weight at $60^{\circ} \mathrm{C}$ in a forced-air oven and ground to pass a $2 \mathrm{~mm}$ screen in a Retsch cutting mill (Germany). Brookside Laboratories Inc. (New Bremen, $\mathrm{OH}$ ) analyzed samples as described in 
TABle 1: Preexperiment soil fertility levels at 15 to $25 \mathrm{~cm}$ depth on six farms in Cát Trinh Commune.

\begin{tabular}{|c|c|c|c|c|c|c|c|c|}
\hline \multirow{2}{*}{ Parameter $^{\mathrm{c}}$} & Overall mean & Overall SD & \multicolumn{6}{|c|}{ Farm means $(n=16)$} \\
\hline & \multicolumn{2}{|c|}{$(n=96)$} & Farm 1 & Farm 2 & Farm 3 & Farm 4 & Farm 5 & Farm 6 \\
\hline $\mathrm{CEC}\left(\mathrm{cmol}_{+} / \mathrm{kg}\right)^{\mathrm{a}}$ & 1.3 & 0.60 & 2.4 & 1.4 & 1.3 & 0.9 & 0.9 & 1.0 \\
\hline $\mathrm{pH}(1: 1$ soil : water $)$ & 5.67 & 0.658 & 5.98 & 5.53 & 6.23 & 5.76 & 4.63 & 5.88 \\
\hline $\mathrm{OM}(\mathrm{g} / \mathrm{kg})^{\mathrm{b}}$ & 3.5 & 2.1 & 5.2 & 4.5 & 2.1 & 1.6 & 5.1 & 2.5 \\
\hline $\mathrm{S}(\mathrm{mg} / \mathrm{kg})$ & 9.1 & 4.47 & 10.1 & 9.9 & 6.3 & 5.6 & 17.0 & 5.6 \\
\hline $\mathrm{P}(\mathrm{mg} / \mathrm{kg})$ & 37 & 27.3 & 67 & 41 & 68 & 22 & 14 & 12 \\
\hline $\mathrm{Ca}(\mathrm{mg} / \mathrm{kg})$ & 176 & 68.3 & 269 & 204 & 190 & 126 & 116 & 151 \\
\hline $\mathrm{Mg}(\mathrm{mg} / \mathrm{kg})$ & 29 & 23.3 & 71 & 19 & 28 & 17 & 21 & 16 \\
\hline K (mg/kg) & 36 & 36.2 & 91 & 41 & 32 & 11 & 31 & 12 \\
\hline $\mathrm{Na}(\mathrm{mg} / \mathrm{kg})$ & 23 & 13.1 & 43 & 20 & 19 & 19 & 21 & 17 \\
\hline B (mg/kg) & 0.18 & 0.19 & 0.25 & 0.38 & 0.24 & 0.01 & 0.15 & 0.04 \\
\hline $\mathrm{Fe}(\mathrm{mg} / \mathrm{kg})$ & 116 & 75.2 & 180 & 142 & 153 & 28 & 169 & 27 \\
\hline $\mathrm{Mn}(\mathrm{mg} / \mathrm{kg})$ & 7 & 7.5 & 14 & 7 & 16 & 1 & 2 & 5 \\
\hline $\mathrm{Cu}(\mathrm{mg} / \mathrm{kg})$ & 1.6 & 1.29 & 3.3 & 2.3 & 1.6 & 0.6 & 1.1 & 0.6 \\
\hline Zn (mg/kg) & 2.7 & 5.43 & 4.4 & 7.1 & 1.5 & 0.4 & 1.0 & 1.6 \\
\hline $\mathrm{Al}(\mathrm{mg} / \mathrm{kg})^{\mathrm{d}}$ & 280 & 179.7 & 375 & 346 & 235 & 116 & 540 & 72 \\
\hline $\mathrm{NO}_{3}-\mathrm{N}(\mathrm{mg} / \mathrm{kg})$ & 3 & 2.6 & 5 & 5 & 1 & 1 & 5 & 2 \\
\hline $\mathrm{NH}_{4}-\mathrm{N}(\mathrm{mg} / \mathrm{kg})$ & 8 & 4.1 & 5 & 15 & 7 & 6 & 8 & 7 \\
\hline $\mathrm{Ca}: \mathrm{Mg}$ & 7.8 & 3.79 & 4.2 & 12.5 & 7.2 & 7.7 & 5.6 & 9.4 \\
\hline
\end{tabular}

${ }^{a} \mathrm{CEC}$ : cation exchange capacity determined by summation of cations $\mathrm{Ca}, \mathrm{Mg}, \mathrm{K}, \mathrm{Na}$, and $\mathrm{H}$, according to Ross [15].

${ }^{\mathrm{b}}$ Soil organic matter $(\mathrm{OM})$ was determined by loss-on-ignition at $360^{\circ} \mathrm{C}[16]$.

${ }^{\mathrm{c}}$ Elements are Mehlich-3 extractable nutrients [17].

${ }^{\mathrm{d}}$ Aluminum toxicity might be an issue due to low $\mathrm{pH}(<5)$ on farm 5 .

Peters et al. [18]. Total $\mathrm{N}$ was determined using an Elementar Vario Max (Elementar Analysensysteme, Hanau, Germany), and minerals were determined using a CEM Mars Express microwave (CEM Corporation, Matthews, NC) with digest analyzed in a Thermo Scientific iCAP 6500 inductively coupled plasma-atomic emission spectrometer (Thermo Electron Corp., Waltman, MA). Ammonium-N and $\mathrm{NO}_{3}-\mathrm{N}$ were determined using a Lachat QuickChem 8000 flow injection calorimetric analyzer (Lachat Instruments, Loveland, CO). Organic matter (OM) was estimated by loss-on-ignition at $550^{\circ} \mathrm{C}$ for $2 \mathrm{~h}$ [18] and mineral matter was calculated as $100-\% \mathrm{OM}$. Average compost treatment composition was 50\% DM, $261 \mathrm{~g} \mathrm{OM} / \mathrm{kg} \mathrm{DM}, 12 \mathrm{~g} \mathrm{~N} / \mathrm{kg} \mathrm{DM}$, $2733 \mathrm{mg} \mathrm{P} / \mathrm{kg} \mathrm{DM}$, and $6750 \mathrm{mg} \mathrm{K} / \mathrm{kg}$ DM (Table 2).

2.4. Experimental Design. Fifteen treatments were derived from the factorial combination of five compost rates $(0,4$, 8,12 , and $24 \mathrm{Mg} \mathrm{DM} / \mathrm{ha}$ per yr) and three urea rates $(0,60$, and $120 \mathrm{~kg} \mathrm{~N} /$ ha per yr). Treatments were implemented in a randomized complete block design on six farms (blocks). A sixteenth treatment added $80 \mathrm{~kg} \mathrm{~K}_{2} \mathrm{O} / \mathrm{ha}$ per yr to the highest compost rate in 2011 and also included the highest urea rate from January 2012 onward. Buffer strips received $4 \mathrm{Mg} \mathrm{DM} /$ ha per yr compost.

Preexperiment compost samples determined field application rates to achieve desired compost $\mathrm{N}$ rates $(0,40$, 80,120 , and $240 \mathrm{~kg} \mathrm{~N} /$ ha per $\mathrm{yr}$ ). Actual $\mathrm{N}$ rates (Table 3 ) differed due to variation in composted manure DM and $\mathrm{N}$ concentrations over time. Treatments were selected to balance for Mulato II $\mathrm{N}$ requirement $(240 \mathrm{~kg} \mathrm{~N} /$ ha per $\mathrm{yr}$ ) with the highest compost treatment. Annual treatments were divided into six parts and applied at approximately 2 mo intervals immediately following each harvest. During the first year, treatments were surface-applied, while second-year treatments were incorporated in the top $15 \mathrm{~cm}$ of soil using handheld hoes to reduce potential for nutrient transfer across plots and to reduce nutrient loss. Initial compost and urea treatments were applied in November 2010 (two months after transplanting) after all Mulato II plants were cut uniformly at $25 \mathrm{~cm}$ above ground level to initiate the experiment.

\subsection{Sampling Protocols}

2.5.1. Soil Samples. Preexperiment soil samples $(n=96)$ were collected in August 2010 using a handheld trowel at a depth of 15 to $25 \mathrm{~cm}$ below ground level (Table 1) and postexperiment samples in May 2013 at two depths (0 to $15 \mathrm{~cm}$ and 15 to $25 \mathrm{~cm}$ ). In each plot, three samples were gathered on a diagonal line across the plot and combined into a single composite sample for each depth. Samples were air-dried, litter was removed, and soil was passed through a $2 \mathrm{~mm}$ sieve. Brookside Laboratories Inc. (New Bremen, $\mathrm{OH})$ determined soil $\mathrm{pH}\left(1: 1 \mathrm{H}_{2} \mathrm{O}\right)$ [23], using an AS-3000 Dual $\mathrm{pH}$ Analyzer, soil $\mathrm{OM}$ by loss-on-ignition at $360^{\circ} \mathrm{C}$ [16], Mehlich-3 [17] extractable P, K, Ca, Mg, S, Na, B, $\mathrm{Mn}, \mathrm{Cu}, \mathrm{Zn}$, and $\mathrm{Al}$ in a Thermo Scientific iCAP 6500 inductively coupled plasma-atomic emission spectrometer (Thermo Electron Corp., Waltman, MA), inorganic $\mathrm{N}\left(\mathrm{NH}_{4}{ }^{-}\right.$ $\mathrm{N}$ and $\mathrm{NO}_{3}-\mathrm{N}$ via $1 \mathrm{~N} \mathrm{KCl}$ cadmium reduction) using a Flow 
TABLE 2: Means and standard deviations for composition of composted cattle manure from the supplying farm in Cát Trinh Commune on a dry matter basis.

\begin{tabular}{lcc}
\hline Parameter & Mean $^{\mathrm{c}}$ & $\mathrm{SD}^{\mathrm{c}}$ \\
\hline Dry matter $(\%)$ & 50 & 8.4 \\
${\text { Organic matter }(\mathrm{g} / \mathrm{kg})^{\mathrm{a}}}^{\mathrm{a}}$ & 261 & 99 \\
${\text { Mineral matter }(\mathrm{g} / \mathrm{kg})^{\mathrm{a}}}_{\mathrm{C} \mathrm{N}^{\mathrm{b}}}$ & 739 & 99 \\
Total N $(\mathrm{g} / \mathrm{kg})$ & 12.8 & 2.3 \\
Organic N $(\mathrm{g} / \mathrm{kg})$ & 12 & 3 \\
$\mathrm{P}(\mathrm{mg} / \mathrm{kg})$ & 11 & 3 \\
$\mathrm{~K}(\mathrm{mg} / \mathrm{kg})$ & 2733 & 1302 \\
$\mathrm{Ca}(\mathrm{mg} / \mathrm{kg})$ & 6750 & 4105 \\
$\mathrm{Mg}(\mathrm{mg} / \mathrm{kg})$ & 9988 & 3581 \\
$\mathrm{Na}(\mathrm{mg} / \mathrm{kg})$ & 3088 & 1094 \\
$\mathrm{~S}(\mathrm{mg} / \mathrm{kg})$ & 955 & 661 \\
$\mathrm{~B}(\mathrm{mg} / \mathrm{kg})$ & 2090 & 516 \\
$\mathrm{Fe}(\mathrm{mg} / \mathrm{kg})$ & 14 & 4 \\
$\mathrm{Mn}(\mathrm{mg} / \mathrm{kg})$ & 4266 & 2196 \\
$\mathrm{Cu}(\mathrm{mg} / \mathrm{kg})$ & 791 & 129 \\
$\mathrm{Zn}(\mathrm{mg} / \mathrm{kg})$ & 27 & 25 \\
\hline
\end{tabular}

${ }^{a}$ Organic matter was estimated by loss-on-ignition at $550^{\circ} \mathrm{C}$ for $2 \mathrm{~h} \mathrm{[18]} \mathrm{and}$ mineral matter was calculated as $100-\% \mathrm{OM}$.

${ }^{\mathrm{b}} 1.724$ factor was applied to convert organic matter (OM) to C, based on the assumption that loss-by-ignition $=\mathrm{OM}$ and $\mathrm{OM}$ contains $58 \%$ organic carbon (Factor of Wolff, as cited in Pribyl [19]).

${ }^{c}$ Means and standard deviations (SD) were calculated from 14 treatment applications, and each treatment application was an average of 3 subsamples.

TABLE 3: Actual nitrogen $(\mathrm{N})$ treatment rates were combinations of urea $\mathrm{N}$ and $\mathrm{N}$ in composted cattle manure.

\begin{tabular}{lccc}
\hline $\begin{array}{l}\text { Compost rate } \\
(\mathrm{ag} \text { DM/ha per yr })\end{array}$ & \multicolumn{3}{c}{ Urea rate $^{\mathrm{a}}$} \\
& 0 & 60 & 120 \\
\hline 0 & 0 & 60 & 120 \\
$4 \pm 0.7$ & $46 \pm 12.4$ & $106 \pm 12.4$ & $166 \pm 12.4$ \\
$8 \pm 1.3$ & $92 \pm 24.9$ & $152 \pm 24.9$ & $212 \pm 24.9$ \\
$12 \pm 2.0$ & $138 \pm 37.3$ & $198 \pm 37.3$ & $258 \pm 37.3$ \\
$24 \pm 4.0$ & $276 \pm 74.7$ & $336 \pm 74.7$ & $396 \pm 74.7$ \\
\hline
\end{tabular}

${ }^{a}$ Error is standard deviation and exists due to variation in compost composition over time during the experiment.

Injection Analyzer (FIAlab Instruments Inc., Bellevue, WA) [24], and cation exchange capacity by summation of cations $\mathrm{Ca}, \mathrm{Mg}, \mathrm{K}, \mathrm{Na}$, and $\mathrm{H}$ [15]. Values below the limit of detection were replaced by limit of detection/2 to enable statistical analysis.

2.5.2. Forage Sampling. Forage plots were harvested every $36 \mathrm{~d}$ with $\mathrm{SD} \pm 8.6 \mathrm{~d}$ (24 total harvest events) during the experiment, starting in January 2011. Farms were harvested in the same order and within two to four days for each harvest event. All fresh forage biomass was weighed for each plot and small subsamples (20 to $50 \mathrm{~g}$ ) were collected to determine dry matter concentration. Every second harvest, larger subsamples (200 to $300 \mathrm{~g}$ ) were collected instead of small subsamples to evaluate forage nutritive value. Samples were dried to stable weight at $60^{\circ} \mathrm{C}$ in a forced-air oven to determine dry matter concentration. Samples were ground to pass a $4 \mathrm{~mm}$ screen in a Retsch cutting mill (Haan, Germany), and those that had not incurred damage from heat or water during the subsequent transportation and storage process were reground to pass a $1 \mathrm{~mm}$ screen in a UDY Cyclone Mill (UDY Corp., Fort Collins, CO). September 2011 and December 2012 samples were analyzed by Dairyland Laboratories Inc. (Arcadia, WI) to determine nutritive value using near infrared spectroscopy [25] with a Foss model 5000 (Foss-NIR System, Silver Spring, MD). Measured parameters included N, P, K, Mg, and Ca. Nutrient uptake in September 2011 and December 2012 was used to calculate partial nutrient balances.

2.5.3. Partial Nutrient Balance and Nitrogen Recovery Calculations. Partial nutrient balances for N, P, and K were calculated as inputs-outputs, where inputs included nutrients applied in fertilizer and compost treatments and outputs were nutrients accumulated in harvested forage. Nutrient outputs were calculated by multiplying back-transformed mean treatment yields (geometric means) by nutrient concentration for each plot in September 2011 samples and December 2012 samples. Nutrient outputs for farm partial nutrient balances were determined using plot yields for September 2011 and December 2012 (in lieu of overall treatment yields) to capture farm-to-farm yield variation. Nitrogen recovery was calculated according to the difference method of Jokela and Randall [20] as \% N recovery $=\left[\left(\mathrm{N}\right.\right.$ uptake in treatment ${ }_{i}-\mathrm{N}$ uptake in zero $\mathrm{N}$ control)/total $\mathrm{N}$ applied in treatment $\left.{ }_{i}\right] \times 100$. Mean treatment yields for the experiment and September 2011 and December 2012 plot nutrient concentration were used to calculate $\mathrm{N}$ uptake.

2.6. Composted Manure Incubation Test. An incubation study was conducted with a representative composted manure sample to test if compost addition resulted in a release of nitrate to the soil or a reduction in nitrate due to immobilization. A New York State fine-loamy soil with a relatively high soil nitrate content $(\mathrm{pH}=7.6, \mathrm{OM}=64 \mathrm{~g} / \mathrm{kg}$, and Morgan $\left.\mathrm{NO}_{3}-\mathrm{N}=17 \mathrm{mg} / \mathrm{kg}\right)(100 \mathrm{~g})$ was amended with $1 \mathrm{~g}$ or $10 \mathrm{~g}$ representative compost (4 replicates) in $450 \mathrm{~mL}$ plastic incubation cups with perforated lids. Cups were arranged in a completely randomized design and incubated at $23^{\circ} \mathrm{C}$ in the dark. Soil moisture was maintained between $70 \%$ and $75 \%$ of field capacity during the incubation. After incubation, samples were dried to stable weight at $50^{\circ} \mathrm{C}$ in a forced-air oven. Subsamples were analyzed for $\mathrm{KCl}$ extractable nitrate [26] in an EasyChem Analyzer (Systea Scientific, Oak Brook, IL).

2.7. Statistical Methods. The effect of compost and urea treatments on soil fertility factors was evaluated in PROC MIXED [27], with fixed effects of compost, urea, compost $\times$ urea, and preexperiment soil fertility, and block as a random effect. Interactions between preexperiment soil fertility 
TABLE 4: Soil chemical models in 0 to $15 \mathrm{~cm}$ and 15 to $25 \mathrm{~cm}$ strata selected from candidate fixed effects of compost (C), urea (U), compost $\times$ urea $(\mathrm{C} \times \mathrm{U})$, preexperiment soil fertility for each parameter sampled at 15 to $25 \mathrm{~cm}$ depth (PSF), and significant interactions, with block included as a random effect.

\begin{tabular}{|c|c|c|c|c|}
\hline \multirow{2}{*}{ Parameter $^{\mathrm{b}}$} & \multicolumn{2}{|c|}{0 to $15 \mathrm{~cm}$ depth } & \multicolumn{2}{|c|}{15 to $25 \mathrm{~cm}$ depth } \\
\hline & Model effect & Farm (\%) & Model effect & $\operatorname{Farm}(\%)^{\mathrm{c}}$ \\
\hline $\mathrm{S}(\mathrm{mg} / \mathrm{kg})$ & $\mathrm{C} \times \mathrm{U} \times \mathrm{PSF}^{\mathrm{a}}$ & 82 & $\mathrm{C} \times \mathrm{U} \times \mathrm{PSF}^{\mathrm{a}}$ & 85 \\
\hline $\mathrm{Mg}(\mathrm{mg} / \mathrm{kg})$ & $\mathrm{C} \times \mathrm{U} \times \mathrm{PSF}^{\mathrm{a}}$ & 87 & $\mathrm{C} \times \mathrm{U} \times \mathrm{PSF}^{\mathrm{a}}$ & 89 \\
\hline $\mathrm{Zn}(\mathrm{mg} / \mathrm{kg})$ & $\mathrm{C} \times \mathrm{U} \times \mathrm{PSF}^{\mathrm{a}}$ & 28 & $\mathrm{C} \times \mathrm{U} \times \mathrm{PSF}^{\mathrm{a}}$ & 16 \\
\hline Mn (mg/kg) & $\mathrm{C} \times \mathrm{PSF}^{\mathrm{a}}$ & 87 & $\mathrm{C} \times \mathrm{U} \times \mathrm{PSF}^{\mathrm{a}}$ & 49 \\
\hline $\mathrm{OM}(\mathrm{g} / \mathrm{kg})$ & $\mathrm{C} \times \mathrm{U} \times \mathrm{PSF}^{\mathrm{a}}$ & 65 & $\mathrm{U} \times \mathrm{PSF}^{\mathrm{a}}$ & 77 \\
\hline $\mathrm{K}(\mathrm{mg} / \mathrm{kg})$ & $\mathrm{C} \times \mathrm{PSF}^{\mathrm{a}}$ & 51 & $\mathrm{C} \times \mathrm{PSF}^{\mathrm{a}}$ & 60 \\
\hline $\mathrm{Cu}(\mathrm{mg} / \mathrm{kg})$ & $\mathrm{C} \times \mathrm{U} \times \mathrm{PSF}^{\mathrm{a}}$ & 62 & PSF & 53 \\
\hline $\mathrm{CEC}\left(\mathrm{cmol}_{+} / \mathrm{kg}\right)$ & PSF & 31 & $\mathrm{C} \times \mathrm{U} \times \mathrm{PSF}^{\mathrm{a}}$ & 46 \\
\hline $\mathrm{P}(\mathrm{mg} / \mathrm{kg})$ & PSF & 52 & $\mathrm{C} \times \mathrm{U} \times \mathrm{PSF}^{\mathrm{a}}$ & 28 \\
\hline $\mathrm{NH}_{4}-\mathrm{N}(\mathrm{mg} / \mathrm{kg})$ & PSF & 66 & $\mathrm{PSF} C \times \mathrm{U}^{\mathrm{a}}$ & 42 \\
\hline $\mathrm{pH}(1: 1$ soil : water $)$ & C PSF & 88 & PSF & 75 \\
\hline $\mathrm{Fe}(\mathrm{mg} / \mathrm{kg})$ & PSF & 88 & PSF & 70 \\
\hline $\mathrm{Al}(\mathrm{mg} / \mathrm{kg})$ & PSF & 62 & PSF & 58 \\
\hline $\mathrm{NO}_{3}-\mathrm{N}(\mathrm{mg} / \mathrm{kg})$ & PSF & 43 & PSF & 46 \\
\hline $\mathrm{Ca}(\mathrm{mg} / \mathrm{kg})$ & $\mathrm{C} \times \mathrm{U}^{\mathrm{a}}$ & 75 & PSF & 49 \\
\hline $\mathrm{Na}(\mathrm{mg} / \mathrm{kg})$ & PSF & 47 & $\mathrm{C} \times \mathrm{U}^{\mathrm{a}}$ & 49 \\
\hline $\mathrm{B}(\mathrm{mg} / \mathrm{kg})$ & NS & - & NS & - \\
\hline
\end{tabular}

${ }^{a}$ Where interactions were significant, only highest level interactive effect or effects are shown, although lower level terms were also in the model.

${ }^{\mathrm{b}}$ Each row represents a single model for each soil depth.

${ }^{\mathrm{c}}$ Percentage of residual variance explained by farm in each model is indicated.

factors and main effects were also evaluated to determine if soil fertility responses depended on initial soil fertility levels. Mean differences among treatments were declared at $P \leq$ 0.05 using Tukey's statistic to control the familywise error rate for multiple comparisons. One-tailed $t$-tests were used to assess paired mean differences between preexperiment and postexperiment soil fertility data, with Bonferroni correction used to identify significant mean differences.

Partial nutrient balance means for the compost $\times$ urea interaction were extracted from mixed models with fixed effects of compost, urea, compost $\times$ urea, and harvest period (September 2011 or December 2012), and included block as a random effect. Models estimating farm partial nutrient balances contained fixed effects of compost, urea, and harvest period (September 2011 or December 2012) and block (farm). Nitrogen recovery means for the compost $\times$ urea interaction for each harvest period were extracted from mixed models with fixed effects of compost, urea, and compost $\times$ urea, and included block as a random effect.

\section{Results}

\subsection{Soil Fertility}

3.1.1. Preexperiment and Postexperiment Soil Fertility. Preexperiment farm soil fertility levels were consistent with yield differences observed in the experiment (i.e., preexperiment soil nutrient concentrations were higher for high-yielding farms). All treatment means $(n=6$ for each compost $\times$ urea interaction rate) were numerically higher in postexperiment samples in the 15 to $25 \mathrm{~cm}$ stratum than preexperiment samples at the same depth for $\mathrm{OM}$ and $\mathrm{NH}_{4}-\mathrm{N}$, and most means were numerically higher after the experiment for $\mathrm{Na}$ and $\mathrm{Fe}$ (Table 8). More than half of postexperiment treatment means were also numerically higher than preexperiment for $\mathrm{Cu}$ and $\mathrm{Mn}$. All treatment means were numerically lower in postexperiment samples at the 15 to $25 \mathrm{~cm}$ stratum than preexperiment samples at the same depth for $\mathrm{S}, \mathrm{P}, \mathrm{K}$, and $\mathrm{NO}_{3}-\mathrm{N}$, and most were lower postexperiment for $\mathrm{pH}, \mathrm{Mg}$, $\mathrm{Al}, \mathrm{Ca}$, and CEC. Significant mean difference (Bonferroni correction) was detected only in soil $\mathrm{Na}$ for compost applied at $12 \mathrm{Mg} \mathrm{DM} / \mathrm{ha}$ per yr without urea, which was higher after the experiment (Table 8).

Models estimating soil fertility parameters in the 15 to $25 \mathrm{~cm}$ stratum (postexperiment level - preexperiment level) indicated that compost impacted differences for soil $\mathrm{Al}(P=$ 0.0189 , ordered 12, 24, 4, 8, and 0, with $12>8$ and 0 ) (Table 9). Urea application decreased soil OM $(P=0.0036$, ordered 0 , 60 , and 120 , with 0 and $60>120)$ and tended to affect $\operatorname{Mg}(P=$ 0.0898 , ordered 0,60 , and 120 , no significant differences) (Table 4). A compost $\times$ urea interaction was detected for $\mathrm{K}$ ( $P=0.0413$, no significant differences $)$, with a tendency to impact $\mathrm{pH}(P=0.0595), \mathrm{Zn}(P=0.0816)$, and $\mathrm{NH}_{4}^{+}$ $(P=0.0985)$.

Preexperiment soil factors (PSF) most highly associated with yield were $\mathrm{Mn}(r=0.48), \mathrm{P}(r=0.44), \mathrm{Fe}(r=0.33)$, exchange capacity $(r=0.32)$, and $\mathrm{Ca}(r=0.32)$. Many preexperiment soil fertility factors were significant in multivariate models with compost and urea main effects (Table 10). Models selected from main effects, PSFs, 


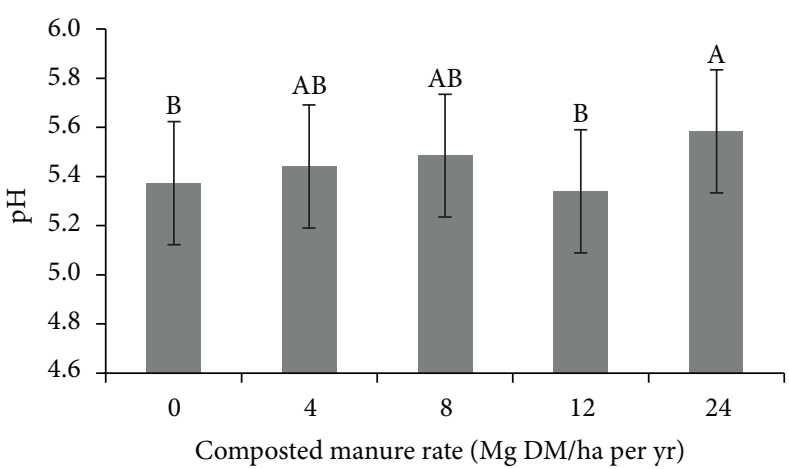

(a) 0 to $15 \mathrm{~cm}$

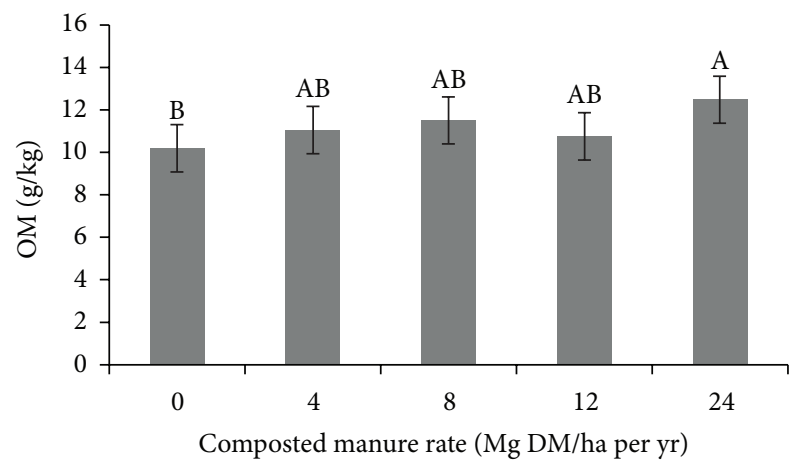

(c) 0 to $15 \mathrm{~cm}$

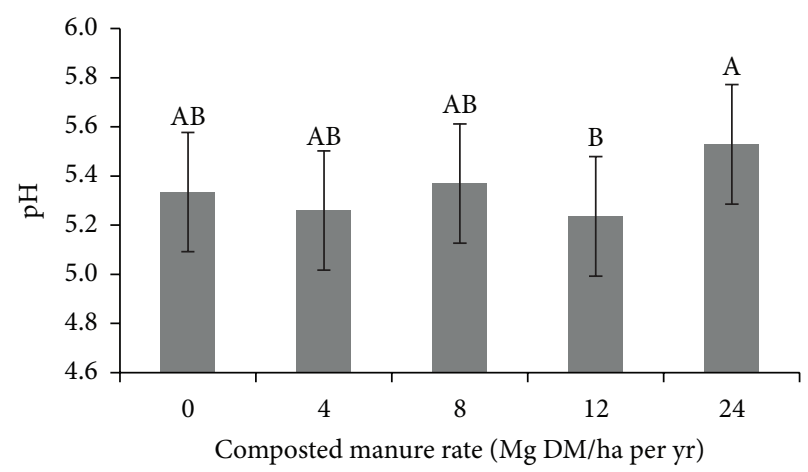

(b) 15 to $25 \mathrm{~cm}$

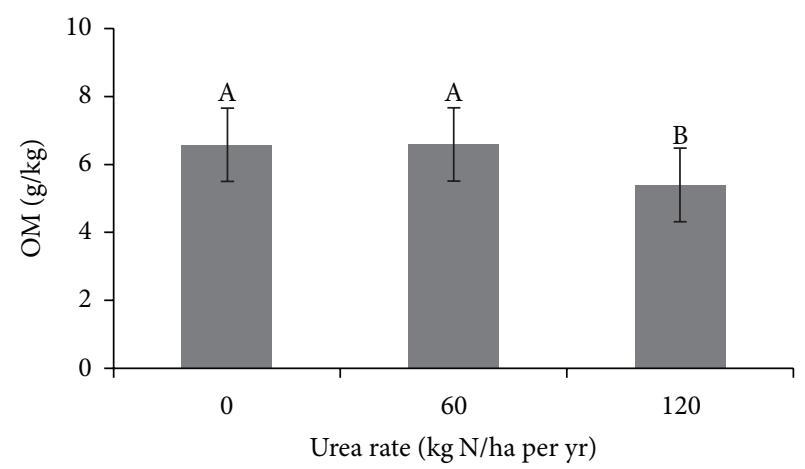

(d) 15 to $25 \mathrm{~cm}$

Figure 1: Postexperiment $\mathrm{pH}$ least squares means for composted manure rates in the 0 to $15 \mathrm{~cm}((\mathrm{a}), P=0.0071)$ and 15 to $25 \mathrm{~cm}$ strata ((b), $P=0.0460)$ and soil organic matter $(\mathrm{OM})$ least square means for compost treatments in the 0 to $15 \mathrm{~cm}$ stratum $((\mathrm{c}), P=0.0087)$ and urea treatments in the 15 to $25 \mathrm{~cm}$ stratum $((\mathrm{d}), P=0.0035)$. $\mathrm{pH}$ models contained preexperiment soil $\mathrm{pH}$ and $\mathrm{OM}$ models contained preexperiment OM (Table 10). Error bars are \pm 1 SE of the mean. Bars connected by the same letter are not significantly different $(P \leq 0.05)$.

and significant interactions indicated the importance of preexperiment soil fertility on treatment responses for some soil fertility parameters (Table 4). The effect of compost and urea (main effects) on postexperiment soil $\mathrm{S}, \mathrm{K}, \mathrm{Mg}, \mathrm{Zn}$, $\mathrm{Mn}$, and OM depended on their respective PSFs for both soil depths. Compost and urea effects on soil $\mathrm{Cu}$ depended on $\mathrm{Cu}$ PSF in the 0 to $15 \mathrm{~cm}$ stratum, while only Cu PSF emerged from the 15 to $25 \mathrm{~cm}$ stratum. The effect of compost and urea on soil CEC and P depended on PSF in the 15 to $25 \mathrm{~cm}$ stratum, while only PSF mattered in the 0 to $15 \mathrm{~cm}$ stratum. The effect of compost and urea on soil $\mathrm{pH}$ at 0 to $15 \mathrm{~cm}$ and $\mathrm{NH}_{4}-\mathrm{N}$ at 15 to $25 \mathrm{~cm}$ did not depend on PSF, although it was in the model. Only PSF emerged from models estimating $\mathrm{Fe}$, $\mathrm{Al}$, and $\mathrm{NO}_{3}-\mathrm{N}$ at both depths, $\mathrm{CEC}, \mathrm{P}, \mathrm{NH}_{4}-\mathrm{N}$, and $\mathrm{Na}$ at 0 to $15 \mathrm{~cm}$, and $\mathrm{Ca}, \mathrm{pH}$, and $\mathrm{Cu}$ at 15 to $25 \mathrm{~cm}$. Preexperiment soil fertility was not significant for $\mathrm{Ca}$ at 0 to $15 \mathrm{~cm}$ or for $\mathrm{Na}$ at 15 to $25 \mathrm{~cm}$. Farm explained greater than $40 \%$ of residual variation in soil fertility models at both depths for all factors except $\mathrm{P}, \mathrm{Zn}$, and CEC.

Compost addition increased soil $\mathrm{pH}$ in both soil strata (Figure 1, Table 10), although $\mathrm{pH}$ for the $12 \mathrm{Mg} \mathrm{DM} /$ ha per $\mathrm{yr}$ compost rate was lower than the $24 \mathrm{Mg} \mathrm{DM} /$ ha per yr rate. Postexperiment soil $\mathrm{pH}$ was highest where compost had been applied, although $\mathrm{pH}$ decreased numerically in most plots relative to preexperiment levels (Table 8). Preexperiment soil $\mathrm{pH}$ (1:1 soil : water) was higher than postexperiment $\mathrm{pH}$ for all treatments in the 15 to $25 \mathrm{~cm}$ stratum, which suggests minor soil acidification during the experiment. The difference between post- and preexperiment $\mathrm{pH}$ was less for the highest compost treatment than $12 \mathrm{Mg} \mathrm{DM} / \mathrm{h}$ a per yr. Postexperiment $\mathrm{pH}$ was impacted by compost treatments. Soil $\mathrm{pH}$ in the 0 to $15 \mathrm{~cm}$ stratum for the highest compost rate $(\mathrm{pH}=5.58)$ was higher than without compost $(\mathrm{pH}=5.37)$ and $12 \mathrm{Mg} \mathrm{DM} / \mathrm{ha}$ per $\mathrm{yr}(\mathrm{pH}=5.33)$ (Figure 1). Response to compost in the 15 to $25 \mathrm{~cm}$ stratum indicated that $\mathrm{pH}$ for the highest compost rate $(\mathrm{pH}=5.53)$ was higher than for the $12 \mathrm{Mg} \mathrm{DM} /$ ha per yr $(\mathrm{pH}=5.24)$ treatment. Overall, the deeper layer was slightly more acidic than the topsoil layer (Figure 1).

Compost increased soil $\mathrm{OM}$ in the 0 to $15 \mathrm{~cm}$ stratum (Figure 1, Table 10). Urea application decreased OM in the 15 to $25 \mathrm{~cm}$ stratum (Figure 1, Table 10). Organic matter for the highest urea rate was lower than the intermediate rate and plots not receiving urea, possibly explained by high mineralization rates in this stratum combined with limited $\mathrm{OM}$ addition to the soil in the form of plant litter. Organic matter in the 15 to $25 \mathrm{~cm}$ stratum for treatment plots increased by $0.8 \mathrm{~g} / \mathrm{kg}$ to $3.8 \mathrm{~g} / \mathrm{kg}$ from preexperiment to postexperiment levels (Table 8).

Consistent with the $\mathrm{OM}$ effect, postexperiment $\mathrm{Ca}$ in the 0 to $15 \mathrm{~cm}$ stratum increased steadily with added compost (Figure 2) and likely contributed to buffering capacity (Figure 2, Table 10). Calcium was higher for the highest 


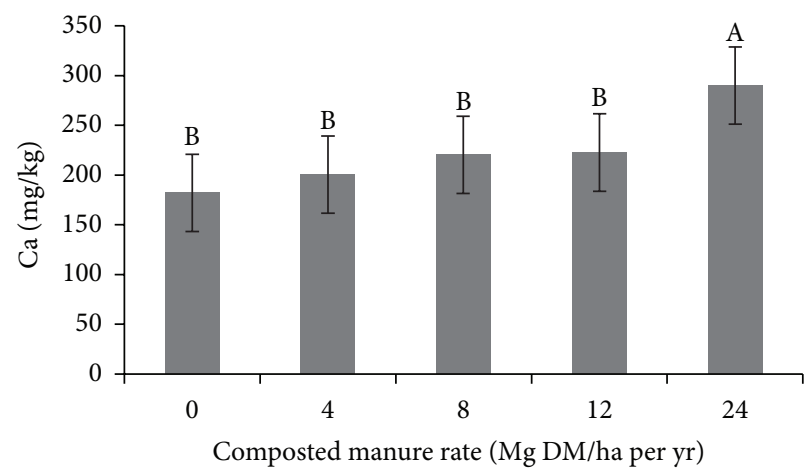

(a) 0 to $15 \mathrm{~cm}$

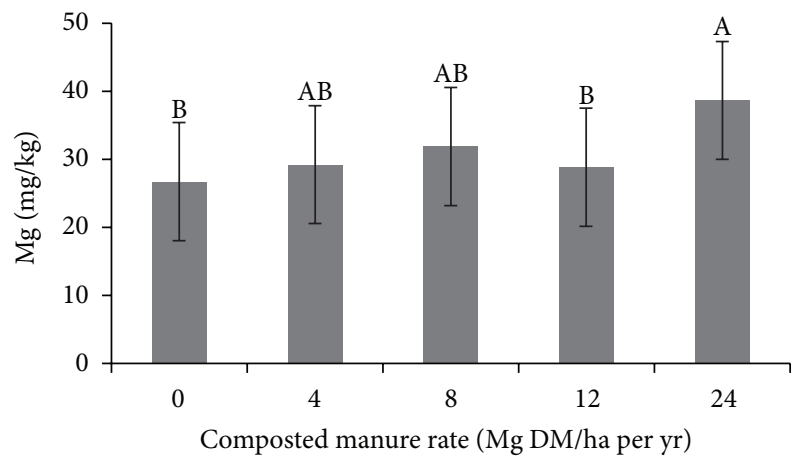

(c) 0 to $15 \mathrm{~cm}$

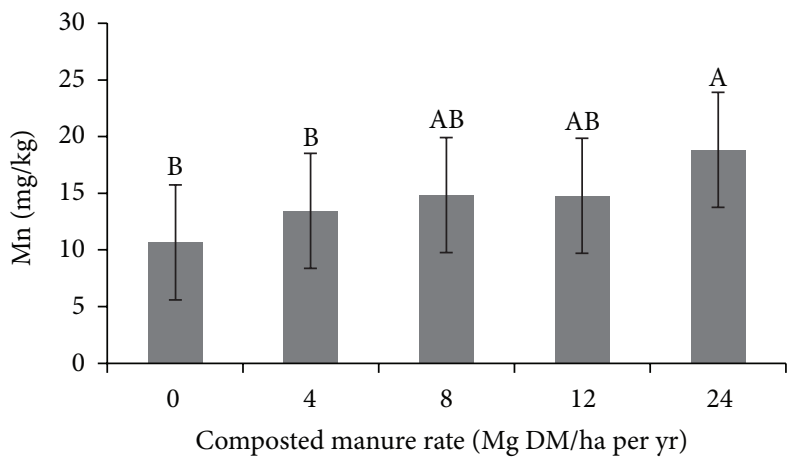

(e) 0 to $15 \mathrm{~cm}$

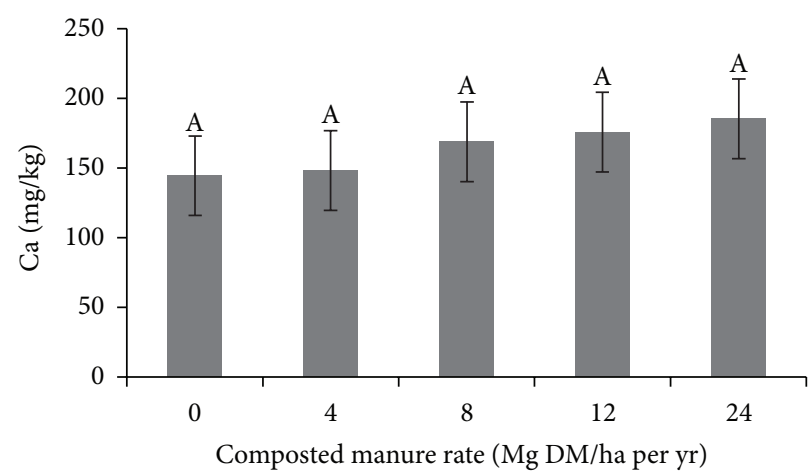

(b) 15 to $25 \mathrm{~cm}$

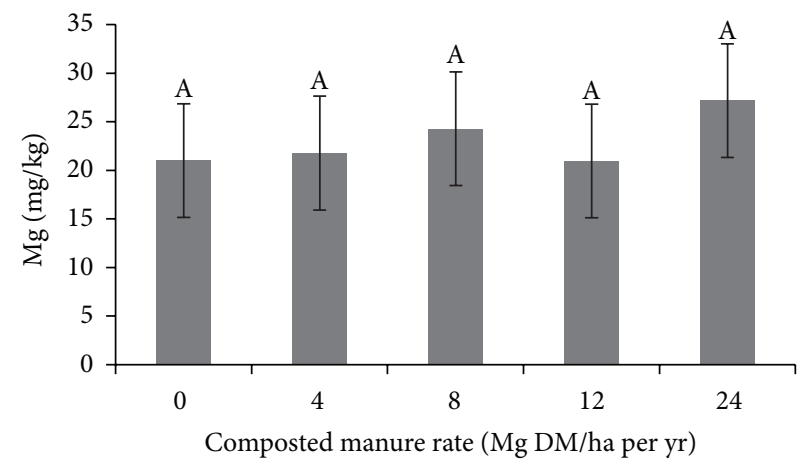

(d) 15 to $25 \mathrm{~cm}$

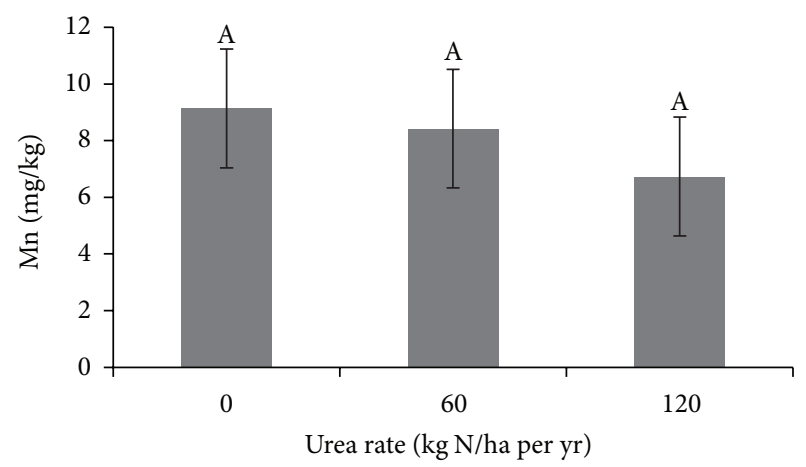

(f) 15 to $25 \mathrm{~cm}$

Figure 2: Postexperiment soil Ca least squares means for composted manure rates in the 0 to $15 \mathrm{~cm}((\mathrm{a}), P<0.0001)$ and 15 to $25 \mathrm{~cm}$ strata ((b), $P=0.1873), \mathrm{Mg}$ least squares means in the 0 to $15 \mathrm{~cm}((\mathrm{c}), P=0.0015)$ and 15 to $25 \mathrm{~cm}((\mathrm{~d}), P=0.0542)$ strata, and Mn least squares means for compost treatments in the 0 to $15 \mathrm{~cm}$ stratum $((\mathrm{e}), P=0.0002)$ and for urea treatments in the 15 to $25 \mathrm{~cm} \mathrm{stratum}((\mathrm{f}), P=0.2015)$. Error bars are $\pm 1 \mathrm{SE}$ of the mean. Bars connected by the same letter are not significantly different $(P \leq 0.05)$. Models contain preexperiment soil fertility factors (Table 10).

compost rate than all other compost treatments. Compost $\times$ urea interaction was also observed (results not shown), but the interaction response was inconsistent. Calcium also increased numerically with applied compost in the 15 to $25 \mathrm{~cm}$ stratum.

Soil $\mathrm{Mg}$ increased with compost treatments in the 0 to $15 \mathrm{~cm}$ stratum, and a trend was observed in the 15 to $25 \mathrm{~cm}$ stratum (Figure 2, Table 10). Similar to soil $\mathrm{pH}, \mathrm{Mg}$ for the highest compost rate was numerically higher than all other treatments and soil $\mathrm{Mg}$ tended to increase with compost application (excepting the $12 \mathrm{Mg} \mathrm{DM} /$ ha per yr plots).
Soil $\mathrm{Mn}$ in the 0 to $15 \mathrm{~cm}$ stratum increased with compost addition, and $\mathrm{Mn}$ for the highest compost rate was higher than $4 \mathrm{Mg} \mathrm{DM} /$ ha per yr and plots not receiving compost (Figure 2, Table 10). Similar to OM, Mn at 15 to $25 \mathrm{~cm}$ depth decreased with added urea, although the effect was not significant $(P=0.2015)$.

Soil $\mathrm{Na}$ responses in the 15 to $25 \mathrm{~cm}$ stratum were probably due to an outlying treatment response. The compost $\times$ urea interaction effects for soil $\mathrm{Na}$ and soil $\mathrm{NH}_{4}-\mathrm{N}$ in this stratum were inconsistent (results not shown). Preexperiment soil $\mathrm{Al}$ levels tended to be higher than postexperiment 
TABLE 5: Nitrate-N extracted from compost-amended soil, control, and nonincubated soil in a laboratory incubation study.

\begin{tabular}{|c|c|c|c|}
\hline $\begin{array}{l}\text { Treatment } \\
\text { (g dry compost added to } 100 \text { g dry soil) }\end{array}$ & $\begin{array}{l}\mathrm{N} \text { treatment equivalent } \\
(\mathrm{kg} \mathrm{N} / \mathrm{ha})\end{array}$ & $\begin{array}{l}\text { Soil nitrate- } \mathrm{N}^{\mathrm{a}} \\
(\mathrm{mg} / \mathrm{kg})\end{array}$ & SE \\
\hline 10 & 2,735 & $161.5 \mathrm{a}$ & 3.36 \\
\hline 1 & 273.5 & $15.7 \mathrm{~b}$ & 3.36 \\
\hline 0 & 0 & $19.5 \mathrm{~b}$ & 3.36 \\
\hline Nonincubated soil & - & $15.2 \mathrm{~b}$ & 3.36 \\
\hline
\end{tabular}

${ }^{a}$ Treatments connected by the same letter are not significantly different $(P \leq 0.05)$.

TABLE 6: Brachiaria cv. Mulato II dry matter yield and N, P, and K balances by farm.

\begin{tabular}{lcccc}
\hline Farm & $\begin{array}{c}\text { Yield }^{\mathrm{a}} \\
(\mathrm{Mg} \mathrm{DM} / \mathrm{ha} / \mathrm{yr})\end{array}$ & $\begin{array}{c}\text { N balance } \\
(\mathrm{kg} \mathrm{N} / \text { ha per yr })\end{array}$ & $\begin{array}{c}\text { P balance }^{\mathrm{bc}} \\
(\mathrm{kg} \mathrm{P} / \text { ha per yr })\end{array}$ & $\begin{array}{c}\text { K balance } \\
(\mathrm{kg} \mathrm{K} / \mathrm{ha} \mathrm{per} \mathrm{yr})\end{array}$ \\
\hline 3 & 26.2 & $-653 \mathrm{e}$ & $-113 \mathrm{~d}$ & $-783 \mathrm{e}$ \\
1 & 16.1 & $-342 \mathrm{~d}$ & $-71 \mathrm{c}$ & $-610 \mathrm{~d}$ \\
2 & 14.8 & $-325 \mathrm{~d}$ & $-57 \mathrm{c}$ & $-388 \mathrm{c}$ \\
5 & 13.3 & $-150 \mathrm{c}$ & $-21 \mathrm{~b}$ & $-186 \mathrm{~b}$ \\
6 & 8.8 & $-56 \mathrm{~b}$ & $-9 \mathrm{ab}$ & $-107 \mathrm{ab}$ \\
4 & 6.6 & $53 \mathrm{a}$ & $7 \mathrm{a}$ & $-38 \mathrm{a}$ \\
\hline
\end{tabular}

${ }^{\mathrm{a}}$ Farm yields are overall experiment means (geometric means).

${ }^{\mathrm{b}}$ Farm N, P, and K balances were calculated using dry matter yield and plot nutrient concentrations for the September 2011 and December 2012 samples.

${ }^{\mathrm{c}}$ Means not connected by the same letter in each column are significantly different $(P \leq 0.05)$.

levels in the 15 to $25 \mathrm{~cm}$ stratum (Table 8). Soil Al for compost applied at $12 \mathrm{Mg} \mathrm{DM} /$ ha per yr was higher (lower mean difference) than $8 \mathrm{MgDM} /$ ha per $\mathrm{yr}$ and without compost (Table 9). This suggests soil Al depletion during the experiment, especially for plots receiving no or a low rate of compost. Compost effect on $\mathrm{Al}$ was not detected in statistical analyses of postexperiment data.

Observed soil fertility effects could be a function of preor postharvest sampling time. Preexperiment samples were collected in August 2010 and postexperiment samples in early May 2013. These soil sampling time frames were both during the dry season but rainfall was slightly higher leading up to August 2010 sampling than May 2013. Soil moisture near sampling times (not measured) could have affected mineralization rates and outcomes.

3.1.2. Incubation Study Results. The compost incubation study confirmed that addition of composted cattle manure at a high rate resulted in rapid $\mathrm{N}$ mineralization and nitrification as expected for material with $\mathrm{C}: \mathrm{N}$ of $13: 1$ (Table 5). The incubation study did not provide evidence of $\mathrm{N}$ immobilization, consistent with the relatively low $\mathrm{C}: \mathrm{N}$ ratio of the compost. However, at the lower application rate, no increase in soil nitrate was determined. The latter supports the hypothesis that the lack of a yield response to compost addition in the farm experiments is due to an insufficient amount applied and not due to immobilization.

3.2. Partial Nutrient Balances and Nitrogen Recovery. Nutrient concentration across the two sampling dates averaged $24 \mathrm{~g} \mathrm{~N} / \mathrm{kg} \mathrm{DM}, 3.8 \mathrm{~g} \mathrm{P} / \mathrm{kg} \mathrm{DM}, 21.2 \mathrm{~g} \mathrm{~K} / \mathrm{kg} \mathrm{DM}, 3.5 \mathrm{~g} \mathrm{Mg} / \mathrm{kg}$ $\mathrm{DM}$, and $6.9 \mathrm{gCa} / \mathrm{kg}$ DM. Average partial $\mathrm{N}, \mathrm{P}$, and $\mathrm{K}$ balances were negative on five of the six farms for $\mathrm{N}$ and $\mathrm{P}$ and negative on all six farms for K (Table 6). Overall partial $\mathrm{N}$ and $\mathrm{P}$ balances on lower-yielding farms were positive or less negative (farms 4, 5, and 6) than for higher-yielding farms (Table 6). Farm-to-farm variation explained a large proportion of residual variance in partial nutrient balances (39\% in $\mathrm{N}$ balance model, $27 \%$ in $\mathrm{P}$ balance model, and $52 \%$ in $\mathrm{K}$ balance model).

Farms with better soil fertility indicators yielded higher, but this also resulted in more negative partial $\mathrm{N}$ balances (Table 6). Variable farm plot histories were also responsible for differences in farm yields. Partial $\mathrm{N}$ balance (Table 7) was most negative for treatments containing low $\mathrm{N}$ inputs and progressively became less negative with additional $\mathrm{N}$ applications as urea and compost. Only the highest compost rate achieved partial $\mathrm{N}$ balances that were close to zero or positive (Table 7). Partial $\mathrm{P}$ and $\mathrm{K}$ balances by farm followed a similar pattern to $\mathrm{N}$, but all $\mathrm{P}$ and $\mathrm{K}$ balances were negative (Table 7). Treatments receiving higher rates of compost were less negative or positive in $\mathrm{P}$ balance. Potassium balances were very negative, impacted more by yield than by compost rates, reflecting the fact that compost $\mathrm{K}$ inputs $(0,26.6,53.2$, 79.9, and $159.7 \mathrm{~kg} \mathrm{~K} /$ ha per $\mathrm{yr}$ ) were low relative to $\mathrm{K}$ removal with harvested forage. Dry season partial nutrient balances were higher due to lower DM yields (not shown).

Greatest $\mathrm{N}$ recovery occurred in plots receiving the highest rate of urea (ranging from 5\% to 42\%) (Table 7). Highest overall $\mathrm{N}$ recovery was observed with $60 \mathrm{~kg} \mathrm{~N} / \mathrm{ha}$ per yr urea $\times 4 \mathrm{Mg} \mathrm{DM} /$ ha per yr compost (79\% and $112 \%$, depending on nutritive value period) due to high dry matter yield for this treatment. Farm-to-farm variation explained $38 \%$ of residual variation in $\mathrm{N}$ recovery for September 2011 samples and 65\% for December 2012. 
TABLE 7: Dry matter yield, partial N, P, and K balances, and nitrogen recovery, by composted manure and urea treatment combinations.

\begin{tabular}{|c|c|c|c|c|c|c|c|}
\hline \multirow[b]{2}{*}{$\begin{array}{l}\text { Compost rate } \\
\text { (Mg DM/ha per yr) }\end{array}$} & \multirow{2}{*}{$\begin{array}{c}\text { Urea rate } \\
(\mathrm{kg} \mathrm{N} / \mathrm{ha} \text { per } \mathrm{yr}) \\
\end{array}$} & \multirow[b]{2}{*}{$\begin{array}{c}\text { Yield } \\
(\mathrm{Mg} \mathrm{DM} / \text { ha per } \mathrm{yr})\end{array}$} & \multirow{2}{*}{$\begin{array}{c}\text { N balance }{ }^{\mathrm{ab}} \\
(\mathrm{kg} \mathrm{N} / \text { ha per yr) }\end{array}$} & \multirow{2}{*}{$\begin{array}{c}\text { P balance }{ }^{\mathrm{ab}} \\
(\mathrm{kg} \mathrm{P} / \text { ha per yr) }\end{array}$} & \multirow{2}{*}{$\begin{array}{c}\mathrm{K}^{\text {balance }}{ }^{\mathrm{ab}} \\
\text { (kg K/ha per yr) }\end{array}$} & \multicolumn{2}{|c|}{ Nitrogen recovery ${ }^{b c}$} \\
\hline & & & & & & $\begin{array}{c}\text { Sept } 2011 \\
(\%)\end{array}$ & $\begin{array}{c}\text { Dec } 2012 \\
(\%)\end{array}$ \\
\hline 24 & 120 & 18.3 & $-67 b c$ & $-5 \mathrm{~b}$ & $-241 \mathrm{bc}$ & $34.0 \mathrm{ab}$ & $42.2 \mathrm{ab}$ \\
\hline 24 & 60 & 12.5 & $32 \mathrm{a}$ & $17 \mathrm{a}$ & $-123 \mathrm{a}$ & $3.0 \mathrm{~b}$ & $-7.8 \mathrm{~b}$ \\
\hline 24 & 0 & 11.7 & $-8 a b$ & $20 \mathrm{a}$ & $-104 \mathrm{a}$ & $-8.5 \mathrm{~b}$ & $-12.4 \mathrm{~b}$ \\
\hline 12 & 120 & 15.4 & $-113 \mathrm{~cd}$ & $-25 d$ & $-258 \mathrm{~cd}$ & $22.4 \mathrm{ab}$ & $23.0 \mathrm{~b}$ \\
\hline 12 & 60 & 15.7 & -168 def & $-25 \mathrm{~d}$ & $-247 \mathrm{bc}$ & $21.4 \mathrm{ab}$ & $32.7 \mathrm{ab}$ \\
\hline 12 & 0 & 12.2 & -153 de & $-13 c$ & $-192 \mathrm{~b}$ & $-10.7 \mathrm{~b}$ & -20.4 \\
\hline 8 & 120 & 15.3 & -155 de & $-36 \mathrm{e}$ & $-263 \mathrm{~cd}$ & $21.0 \mathrm{ab}$ & $30.3 \mathrm{ab}$ \\
\hline 8 & 60 & 13.3 & -160 de & $-28 \mathrm{~d}$ & $-230 \mathrm{bc}$ & $0.5 \mathrm{~b}$ & $-0.6 \mathrm{~b}$ \\
\hline 8 & 0 & 12.8 & -208 efg & $-26 \mathrm{~d}$ & $-216 \mathrm{bc}$ & $-13.1 b$ & $-13.0 \mathrm{~b}$ \\
\hline 4 & 120 & 14.1 & -181 def & $-42 \mathrm{fg}$ & $-248 \mathrm{bc}$ & $23.4 \mathrm{ab}$ & $17.9 \mathrm{~b}$ \\
\hline 4 & 60 & 16.7 & -307 hi & $-52 \mathrm{~h}$ & $-316 d$ & $78.5 \mathrm{a}$ & $112.2 \mathrm{a}$ \\
\hline 4 & 0 & 12.8 & -264 ghi & -38 ef & $-240 \mathrm{bc}$ & $1.1 \mathrm{~b}$ & $-10.8 \mathrm{~b}$ \\
\hline 0 & 120 & 13.6 & $-202 \mathrm{efg}$ & $-49 \mathrm{~h}$ & $-280 \mathrm{~cd}$ & $10.6 \mathrm{ab}$ & $5.0 \mathrm{~b}$ \\
\hline 0 & 60 & 12.5 & $-236 \mathrm{fgh}$ & $-47 \mathrm{gh}$ & $-276 \mathrm{~cd}$ & $-13.5 b$ & $-42.2 \mathrm{~b}$ \\
\hline 0 & 0 & 12.6 & $-312 \mathrm{i}$ & $-47 \mathrm{gh}$ & $-240 \mathrm{bc}$ & - & - \\
\hline
\end{tabular}

${ }^{a}$ Balances were calculated using overall dry matter yield treatment means and plot treatment nutrient concentrations from September 2011 and December 2012 samples.

${ }^{\mathrm{b}}$ Means not connected by the same letter in each column are significantly different $(P \leq 0.05)$.

${ }^{\mathrm{c}}$ Nitrogen recovery was calculated according to Jokela and Randall [20] as \% $\mathrm{N}$ recovery $=\left[\left(\mathrm{N}\right.\right.$ uptake in treatment $t_{i}-\mathrm{N}$ uptake in zero $\mathrm{N}$ control)/total $\mathrm{N}$ applied in treatment $\left.t_{i}\right] \times 100$. Nitrogen recovery was based on overall dry matter yield treatment means and application rates in September 2011 and December 2012 .

\section{Discussion}

4.1. Soil Fertility. Mehlich-3 soil test guidelines for agronomic crops in the subtropics (Florida) suggest medium levels at 26 to $40 \mathrm{mg} / \mathrm{kg} \mathrm{P,} 26$ to $40 \mathrm{mg} / \mathrm{kg} \mathrm{K}$, and 11 to $23 \mathrm{mg} / \mathrm{kg} \mathrm{Mg} \mathrm{[28].}$ Although local calibration experiments should be conducted, these results suggest the potential for $\mathrm{P}$ and $\mathrm{K}$ deficiency in our experiment (medium range), while $\mathrm{Mg}$ is sufficiently high. Alternative interpretation guidelines for forage crops in temperate US regions suggest that $\mathrm{P}, \mathrm{K}$, and $\mathrm{Mg}$ levels are below optimum for forage crops (optimum range is 30 to $50 \mathrm{mg} / \mathrm{kg}$ for P, 100 to $200 \mathrm{mg} / \mathrm{kg}$ for $\mathrm{K}$, and 120 to $180 \mathrm{mg} / \mathrm{kg}$ for $\mathrm{Mg}$ ) [29]. Variability in soil fertility among farms was high as indicated by large standard deviations for most elements; preexperiment soil nutrient concentrations were higher for high-yielding farms. The interaction of preexperiment soil fertility with main compost and urea effects for OM and some macro- and micronutrients in compost (P, K, Mg, S, Zn, Mn, and $\mathrm{Cu}$ ) suggests that the ability to maintain soil fertility is dependent on the interaction between soil organic and inorganic amendments and existing soil fertility. These observations support the hypothesis that soils are deficient in multiple nutrients and that compost supplies most soil nutrients but insufficient $\mathrm{N}$, while urea application can address the $\mathrm{N}$ shortfall.

Soil OM increase during the experiment also took place in plots that did not receive compost, indicating that litter from aboveground and belowground plant biomass may be accumulating over time. Combination of OM from compost and from Mulato II leaf and root residues probably contributed to higher topsoil OM. Compost may play an important role in maintaining or perhaps increasing soil OM over time. Soil Mn was most highly correlated with yield and there were possible Mn deficiencies on some farms with low preexperiment Mn levels (plots at or below $1 \mathrm{mg} \mathrm{Mn} / \mathrm{kg}$ ) that were ameliorated by compost mineralization over time, further supporting the hypothesis that compost addition increases soil fertility status.

4.2. Partial Nutrient Balances. Farms represented a range in tropical sandy soils in the region. Preexperiment soil fertility and field histories differed substantially among participating farms. These conditions, combined with variation in rainfall and irrigation, resulted in large yield differences among farms. In general, preexperiment soil fertility was better for the three farms (farms 1,2, and 3) with the highest yields and most negative $\mathrm{N}, \mathrm{P}$, and $\mathrm{K}$ balances. However, residual soil nutrients are unlikely to entirely account for the observed negative balances in Arenosols with low CEC $\left(1.3 \mathrm{cmol}_{+} / \mathrm{kg}\right.$ with $\mathrm{SD} \pm 0.57)$ and low organic matter $(0.35 \%$ with $\mathrm{SD} \pm$ 0.21) (Table 1). Negative balances suggest that yields will not be sustainable over time even for the highest input levels used in this experiment. For example, DM yield of $20 \mathrm{Mg} / \mathrm{ha}$ per yr with $24 \mathrm{~g} \mathrm{~N} / \mathrm{kg}$ DM removes $480 \mathrm{~kg} \mathrm{~N} /$ ha per yr through forage mass. Supplying $480 \mathrm{~kg} \mathrm{~N} /$ ha per yr with the cheapest commercial $\mathrm{N}$ fertilizer available in Vietnam (urea, $46 \% \mathrm{~N}$, $\$ 0.56 \mathrm{USD} / \mathrm{kg}$ in 2013 ) would require $1043 \mathrm{~kg}$ urea at a total cost of $\$ 584 \mathrm{USD} / \mathrm{ha}$ per yr. This calculation assumes no losses and application at the crop removal rate, assuming limited soil N supply. Supply of other nutrients in addition to 
TABLE 8: Soil fertility means before and after the experiment at the 15 to $25 \mathrm{~cm}$ depth for compost $\times$ urea treatment combinations. Elements are Mehlich-3 extractable nutrients. Data from before the experiment are included as a treatment baseline. Means calculated in each cell are an average of 6 farms. The only pair that differed significantly based on a paired one-tailed $t$-test, using the Bonferroni-adjusted $P$ value cutoff of 0.003 , is in bold.

\begin{tabular}{|c|c|c|c|c|c|c|c|c|c|c|c|c|c|c|c|}
\hline \multirow{3}{*}{ Parameter } & \multicolumn{15}{|c|}{ Compost treatment (Mg DM/ha per yr) / urea treatment (kg N/ha per yr) } \\
\hline & 0 & 4 & 8 & 12 & 24 & 0 & 4 & 8 & 12 & 24 & 0 & 4 & 8 & 12 & 24 \\
\hline & 0 & 0 & 0 & 0 & 0 & 60 & 60 & 60 & 60 & 60 & 120 & 120 & 120 & 120 & 120 \\
\hline Before $\mathrm{pH}$ ( $1: 1$ soil : water $)$ & 5.37 & 5.98 & 5.63 & 5.87 & 5.68 & 5.52 & 5.27 & 5.83 & 5.83 & 5.63 & 5.72 & 5.50 & 5.82 & 5.75 & 5.45 \\
\hline After pH (1: 1 soil : water) & 5.05 & 5.30 & 5.47 & 5.48 & 5.67 & 5.58 & 5.05 & 5.48 & 5.37 & 5.50 & 5.18 & 5.32 & 5.32 & 5.10 & 5.32 \\
\hline Before CEC $\left(\mathrm{cmol}_{+} / \mathrm{kg}\right)$ & 1.19 & 1.16 & 1.19 & 1.22 & 1.53 & 1.52 & 1.20 & 1.40 & 1.29 & 1.43 & 1.33 & 1.17 & 1.35 & 1.28 & 1.23 \\
\hline After CEC $\left(\mathrm{cmol}_{+} / \mathrm{kg}\right)$ & 0.922 & 1.10 & 1.13 & 1.16 & 1.47 & 1.69 & 1.05 & 1.26 & 1.26 & 1.26 & 1.14 & 1.04 & 1.31 & 1.44 & 1.25 \\
\hline Before OM (g/kg) & 4.07 & 2.58 & 2.87 & 3.05 & 4.15 & 4.68 & 3.28 & 3.35 & 3.13 & 3.87 & 3.98 & 3.47 & 3.15 & 4.22 & 3.15 \\
\hline After OM (g/kg) & 6.82 & 5.5 & 5.97 & 6.65 & 7.23 & 6.62 & 7.12 & 6.13 & 6.1 & 7.48 & 4.8 & 4.98 & 5.53 & 6.32 & 5.58 \\
\hline Before S (mg/kg) & 9.67 & 8.00 & 9.33 & 7.50 & 9.50 & 9.67 & 9.33 & 8.67 & 8.67 & 10.30 & 9.83 & 9.17 & 8.17 & 8.50 & 9.00 \\
\hline After S (mg/kg) & 8.67 & 6.83 & 7.17 & 7.33 & 7.67 & 6.67 & 8.50 & 7.00 & 7.67 & 7.50 & 8.33 & 7.33 & 7.67 & 7.67 & 7.33 \\
\hline Before P (mg/kg) & 36.5 & 37.7 & 36.5 & 27.2 & 39.0 & 50.8 & 33.2 & 46.2 & 34.2 & 39.7 & 36.2 & 37.3 & 42.8 & 29.3 & 37.3 \\
\hline After P (mg/kg) & 25.3 & 18.5 & 24.2 & 23.5 & 36.5 & 29.0 & 27.7 & 26.5 & 22.0 & 24.2 & 23.2 & 20.7 & 25.3 & 17.0 & 24.2 \\
\hline Before Ca (mg/kg) & 165 & 159 & 165 & 178 & 207 & 198 & 170 & 193 & 159 & 201 & 174 & 162 & 179 & 165 & 150 \\
\hline After Ca (mg/kg) & 119 & 156 & 154 & 163 & 220 & 181 & 141 & 168 & 185 & 174 & 136 & 141 & 187 & 176 & 169 \\
\hline Before $\mathrm{Mg}(\mathrm{mg} / \mathrm{kg})$ & 25.8 & 22.0 & 23.5 & 22.0 & 30.2 & 31.8 & 22.8 & 31.3 & 33.2 & 29.2 & 34.3 & 23.5 & 30.7 & 27.7 & 34.2 \\
\hline After Mg (mg/kg) & 20.8 & 20.2 & 23.8 & 24.8 & 26.7 & 24.0 & 21.7 & 23.5 & 21.5 & 26.5 & 20.0 & 19.7 & 25.8 & 16.2 & 30.5 \\
\hline Before K (mg/kg) & 24.3 & 35.5 & 32.7 & 23.2 & 47.3 & 64.8 & 25.7 & 29.5 & 48.3 & 32.5 & 26.5 & 29.5 & 38.7 & 33.5 & 38.2 \\
\hline After K (mg/kg) & 12.3 & 10.7 & 10.8 & 11.8 & 10.2 & 16.0 & 12.2 & 12.0 & 11.0 & 12.5 & 11.0 & 11.5 & 11.8 & 10.7 & 12.0 \\
\hline Before $\mathrm{Na}(\mathrm{mg} / \mathrm{kg})$ & 21.3 & 20.7 & 20.5 & 18.8 & 28.8 & 21.2 & 20.3 & 22.5 & 21.3 & 23.7 & 24.2 & 20.8 & 24.5 & 32.5 & 22.7 \\
\hline After Na (mg/kg) & 28.2 & 29.7 & 29.3 & 25.0 & 27.5 & 42.3 & 30.5 & 28.2 & 28.0 & 32.0 & 26.3 & 32.0 & 28.8 & 28.3 & 27.8 \\
\hline Before B (mg/kg) & 0.135 & 0.170 & 0.228 & 0.208 & 0.243 & 0.203 & 0.135 & 0.148 & 0.100 & 0.262 & 0.230 & 0.075 & 0.203 & 0.127 & 0.138 \\
\hline After B (mg/kg) & 0.262 & 0.115 & 0.125 & 0.090 & 0.170 & 0.290 & 0.223 & 0.100 & 0.207 & 0.128 & 0.300 & 0.235 & 0.143 & 0.183 & 0.313 \\
\hline Before Fe (mg/kg) & 132 & 123 & 116 & 97.8 & 116 & 153 & 106 & 127 & 115 & 132 & 100 & 128 & 107 & 109 & 114 \\
\hline After Fe (mg/kg) & 138 & 112 & 120 & 132 & 148 & 154 & 125 & 135 & 127 & 125 & 108 & 122 & 152 & 120 & 121 \\
\hline Before Mn (mg/kg) & 8.50 & 5.83 & 5.17 & 8.17 & 8.17 & 10.5 & 6.17 & 5.67 & 8.00 & 6.00 & 6.33 & 6.67 & 8.83 & 11.5 & 5.33 \\
\hline After Mn (mg/kg) & 6.50 & 7.00 & 10.0 & 8.00 & 13.7 & 8.00 & 9.67 & 7.00 & 11.0 & 6.17 & 6.17 & 5.33 & 9.33 & 7.50 & 6.17 \\
\hline Before $\mathrm{Cu}(\mathrm{mg} / \mathrm{kg})$ & 1.74 & 1.11 & 1.19 & 1.24 & 1.76 & 1.45 & 1.20 & 1.50 & 1.69 & 1.50 & 2.05 & 1.94 & 1.17 & 2.39 & 1.56 \\
\hline After Cu (mg/kg) & 1.81 & 1.65 & 2.02 & 1.67 & 1.73 & 1.73 & 1.74 & 1.59 & 1.44 & 2.05 & 1.99 & 1.69 & 2.24 & 2.02 & 1.68 \\
\hline Before $\mathrm{Zn}(\mathrm{mg} / \mathrm{kg})$ & 2.45 & 1.45 & 2.06 & 3.20 & 3.14 & 2.72 & 1.88 & 1.64 & 1.76 & 2.11 & 3.69 & 2.09 & 2.05 & 10.60 & 1.61 \\
\hline After Zn (mg/kg) & 1.37 & 2.12 & 2.17 & 5.97 & 3.53 & 4.13 & 1.84 & 1.59 & 1.89 & 2.42 & 3.57 & 1.98 & 3.89 & 2.25 & 1.60 \\
\hline Before Al (mg/kg) & 293 & 235 & 306 & 244 & 273 & 285 & 289 & 339 & 246 & 267 & 369 & 292 & 249 & 225 & 265 \\
\hline After Al (mg/kg) & 250 & 192 & 245 & 257 & 254 & 221 & 267 & 248 & 230 & 202 & 313 & 210 & 245 & 230 & 242 \\
\hline Before $\mathrm{NO}_{3}-\mathrm{N}(\mathrm{mg} / \mathrm{kg})$ & 3.93 & 2.40 & 2.40 & 2.67 & 5.10 & 3.87 & 3.15 & 1.90 & 3.32 & 2.68 & 1.67 & 2.78 & 3.48 & 4.57 & 2.45 \\
\hline After $\mathrm{NO}_{3}-\mathrm{N}(\mathrm{mg} / \mathrm{kg})$ & 1.37 & 1.33 & 0.77 & 1.25 & 0.400 & 0.450 & 1.87 & 0.533 & 1.48 & 0.650 & 0.850 & 0.433 & 1.98 & 2.57 & 1.12 \\
\hline Before $\mathrm{NH}_{4}-\mathrm{N}(\mathrm{mg} / \mathrm{kg})$ & 8.90 & 6.13 & 8.30 & 6.73 & 7.60 & 8.88 & 8.57 & 8.65 & 8.72 & 8.17 & 9.73 & 8.25 & 7.72 & 6.70 & 7.77 \\
\hline After $\mathrm{NH}_{4}-\mathrm{N}(\mathrm{mg} / \mathrm{kg})$ & 13.5 & 9.52 & 9.82 & 10.2 & 10.1 & 10.2 & 12.4 & 9.92 & 10.6 & 10.7 & 11.0 & 10.4 & 13.5 & 10.8 & 10.6 \\
\hline
\end{tabular}

$\mathrm{N}$ could be achieved using composted cattle manure if applied in sufficient amounts.

The $24 \mathrm{MgDM} /$ ha per $\mathrm{yr}$ of compost added in the experiment contained approximately $279 \mathrm{~kg} \mathrm{~N}, 66 \mathrm{~kg}$ P, $162 \mathrm{~kg}$ $\mathrm{K}, 74 \mathrm{~kg} \mathrm{Mg}$, and $240 \mathrm{~kg} \mathrm{Ca}$. Maximum $\mathrm{N}$ release for compost mineralization combined with urea application at removal rate could be sufficient to support a $20 \mathrm{MgDM}$ /ha per yr yield with assumed losses of $40 \%$ of total $\mathrm{N}$ applied. Nutrient removal estimates with a $20 \mathrm{Mg} / \mathrm{ha}$ per yr yield $(75 \mathrm{~kg} \mathrm{P} / \mathrm{yr}$, $424 \mathrm{~kg} \mathrm{~K} / \mathrm{yr}, 70 \mathrm{~kg} \mathrm{Mg} / \mathrm{yr}$, and $137 \mathrm{~kg} \mathrm{Ca} / \mathrm{yr}$ ) suggest that only the supplies of $\mathrm{Mg}$ and $\mathrm{P}$ were adequate while $\mathrm{K}$ supply remained insufficient $(-262 \mathrm{~kg} / \mathrm{ha}$ per $\mathrm{yr})$. Yet a response to added $\mathrm{K}$ was not observed in this experiment, suggesting some capacity of the soil to supply K despite low postexperiment soil test levels or that availability of other soil nutrients may have been more limiting than K. Grasses exhibit luxury consumption of $\mathrm{K}$, although yield may remain stable with herbage $\mathrm{K}$ concentrations as low as $13 \mathrm{~g} \mathrm{~K} / \mathrm{kg} \mathrm{DM}$ [30].

Nutrient recycling from decaying aboveground and belowground Mulato II litter could supply additional nutrients. In a grazing system with Brachiaria humidicola pastures in Brazil, Boddey et al. [31] discovered litter deposits as high as $170 \mathrm{~kg} \mathrm{~N} /$ ha per yr (30 Mg DM/ha per yr) with low stocking rates. Magnitude of litter contributions is unknown in this 
TABLE 9: Treatment $P$ values for the difference between postexperiment soil fertility parameters and preexperiment parameters in the 15 to $25 \mathrm{~cm}$ stratum. Each row represents a single model. Models include block as a random effect. Elemental analyses are for Mehlich-3 extractable elements. Significant effects $(P \leq 0.05)$ are in bold.

\begin{tabular}{lccc}
\hline Parameter & Compost & Urea & Compost $\times$ urea \\
\hline Total exchange capacity $\left(\mathrm{cmol}_{+} / \mathrm{kg}\right)$ & 0.9317 & 0.8727 & 0.8756 \\
$\mathrm{pH}(1: 1 \mathrm{soil}:$ water $)$ & $\mathbf{0 . 0 2 6 9}$ & 0.1749 & 0.0595 \\
Organic matter $(\mathrm{g} / \mathrm{kg})$ & 0.1604 & $\mathbf{0 . 0 0 3 6}$ & 0.7973 \\
$\mathrm{~S}(\mathrm{mg} / \mathrm{kg})$ & 0.3240 & 0.4647 & 0.7185 \\
$\mathrm{P}(\mathrm{mg} / \mathrm{kg})$ & 0.4661 & 0.2771 & 0.4179 \\
$\mathrm{Ca}(\mathrm{mg} / \mathrm{kg})$ & 0.4523 & 0.8386 & 0.8740 \\
$\mathrm{Mg}(\mathrm{mg} / \mathrm{kg})$ & 0.3694 & 0.0898 & 0.6977 \\
$\mathrm{~K}(\mathrm{mg} / \mathrm{kg})$ & 0.7658 & 0.4829 & $\mathbf{0 . 0 4 1 3}$ \\
$\mathrm{Na}(\mathrm{mg} / \mathrm{kg})$ & 0.2887 & 0.1182 & 0.4206 \\
$\mathrm{~B}(\mathrm{mg} / \mathrm{kg})$ & 0.2849 & 0.1422 & 0.5266 \\
$\mathrm{Fe}(\mathrm{mg} / \mathrm{kg})$ & 0.3824 & 0.6983 & 0.1219 \\
$\mathrm{Mn}(\mathrm{mg} / \mathrm{kg})$ & 0.2557 & 0.2068 & 0.4542 \\
$\mathrm{Cu}(\mathrm{mg} / \mathrm{kg})$ & 0.1078 & 0.4458 & 0.1693 \\
$\mathrm{Zn}(\mathrm{mg} / \mathrm{kg})$ & 0.7921 & 0.2485 & 0.0816 \\
$\mathrm{Al}(\mathrm{mg} / \mathrm{kg})$ & $\mathbf{0 . 0 1 8 9}$ & 0.2622 & 0.1371 \\
$\mathrm{NO}{ }_{3}-\mathrm{N}(\mathrm{mg} / \mathrm{kg})$ & 0.4310 & 0.4914 & 0.1622 \\
$\mathrm{NH}-\mathrm{N}(\mathrm{mg} / \mathrm{kg})$ & 0.9296 & 0.3301 & 0.0985 \\
\hline
\end{tabular}

TABle 10: $P$ values for treatment effects on soil chemical properties in 0 to $15 \mathrm{~cm}$ and 15 to $25 \mathrm{~cm}$ strata for models containing fixed effects of compost $(\mathrm{C})$, urea $(\mathrm{U})$, compost $\times$ urea $(\mathrm{C} \times \mathrm{U})$, and preexperiment soil fertility measurement for each parameter sampled at 15 to $25 \mathrm{~cm}$ depth (PSF), with block as a random effect. Each row represents a single model for each soil depth. Significant values at $P \leq 0.05$ are in bold.

\begin{tabular}{|c|c|c|c|c|c|c|c|c|}
\hline \multirow{2}{*}{ Parameter } & $\mathrm{C}$ & $\mathrm{U}$ & $\mathrm{C} \times \mathrm{U}$ & \multirow[t]{2}{*}{ PSF } & $\mathrm{C}$ & $\mathrm{U}$ & $\mathrm{C} \times \mathrm{U}$ & \multirow[t]{2}{*}{ PSF } \\
\hline & \multicolumn{3}{|c|}{0 to $15 \mathrm{~cm}$ depth } & & \multicolumn{3}{|c|}{15 to $25 \mathrm{~cm}$ depth } & \\
\hline $\mathrm{CEC}\left(\mathrm{cmol}_{+} / \mathrm{kg}\right)$ & 0.2145 & 0.6271 & 0.3142 & 0.0797 & 0.6827 & 0.5997 & 0.4332 & 0.0363 \\
\hline pH (1:1 soil : water $)$ & 0.0071 & 0.1196 & 0.0705 & $<0.0001$ & 0.0460 & 0.1071 & 0.0856 & $<0.0001$ \\
\hline $\mathrm{OM}(\mathrm{g} / \mathrm{kg})$ & 0.0087 & 0.6440 & 0.0505 & $<0.0001$ & 0.2699 & 0.0035 & 0.7938 & $<0.0001$ \\
\hline $\mathrm{S}(\mathrm{mg} / \mathrm{kg})$ & 0.2249 & 0.9163 & 0.0720 & 0.2507 & 0.8146 & 0.7345 & 0.1171 & 0.0547 \\
\hline $\mathrm{P}(\mathrm{mg} / \mathrm{kg})$ & 0.6723 & 0.5556 & 0.3621 & 0.0157 & 0.6537 & 0.3633 & 0.4554 & 0.0001 \\
\hline $\mathrm{Ca}(\mathrm{mg} / \mathrm{kg})$ & $<0.0001$ & 0.4688 & 0.0147 & 0.0718 & 0.1873 & 0.9323 & 0.6124 & 0.2071 \\
\hline Mg (mg/kg) & 0.0015 & 0.2469 & 0.2219 & 0.0540 & 0.0542 & 0.4886 & 0.4991 & 0.0006 \\
\hline $\mathrm{K}(\mathrm{mg} / \mathrm{kg})$ & 0.1703 & 0.3593 & 0.7202 & 0.0301 & 0.2833 & 0.1041 & 0.3959 & 0.3572 \\
\hline $\mathrm{Na}(\mathrm{mg} / \mathrm{kg})$ & 0.0788 & 0.6333 & 0.8865 & 0.0446 & 0.1636 & 0.0246 & 0.0201 & 0.3319 \\
\hline $\mathrm{B}(\mathrm{mg} / \mathrm{kg})$ & 0.0954 & 0.4529 & 0.4883 & 0.9517 & 0.0788 & 0.2146 & 0.8916 & 0.5975 \\
\hline $\mathrm{Fe}(\mathrm{mg} / \mathrm{kg})$ & 0.9956 & 0.4733 & 0.2342 & 0.0020 & 0.4978 & 0.9109 & 0.1584 & $<0.0001$ \\
\hline Mn (mg/kg) & 0.0002 & 0.4951 & 0.6742 & 0.9859 & 0.5170 & 0.2015 & 0.3686 & 0.0002 \\
\hline $\mathrm{Cu}(\mathrm{mg} / \mathrm{kg})$ & 0.5569 & 0.3744 & 0.5829 & 0.0343 & 0.3963 & 0.8292 & 0.4546 & 0.0003 \\
\hline $\mathrm{Zn}(\mathrm{mg} / \mathrm{kg})$ & 0.8383 & 0.6481 & 0.2006 & 0.1849 & 0.9202 & 0.5418 & 0.0771 & 0.0046 \\
\hline $\mathrm{Al}(\mathrm{mg} / \mathrm{kg})$ & 0.6086 & 0.4611 & 0.6980 & $<0.0001$ & 0.1240 & 0.2865 & 0.1456 & $<0.0001$ \\
\hline $\mathrm{NO}_{3}-\mathrm{N}(\mathrm{mg} / \mathrm{kg})$ & 0.5608 & 0.2398 & 0.2026 & 0.1510 & 0.1936 & 0.4103 & 0.2641 & 0.0885 \\
\hline $\mathrm{NH}_{4}-\mathrm{N}(\mathrm{mg} / \mathrm{kg})$ & 0.1017 & 0.6409 & 0.1306 & 0.0155 & 0.9530 & 0.5630 & 0.0386 & 0.0068 \\
\hline
\end{tabular}

experiment, but litter could make a large and important contribution to annual nutrient supply. Further experimentation is necessary in sandy tropical soils to obtain more accurate estimates of nutrient balances.

Reasons reported for yield persistence (despite negative balances) during postexperiment discussions with participating farmers include nutrient uptake from buffers and neighboring plots and soil nutrient reserves. Brachiaria spp. grasses are deep-rooted, which can help improve soil properties and transfer nutrients from deeper layers [32]. Assessment of the soil fertility status of deeper soil layers was not done for this study. Additionally, rising water tables during the rainy season may bring dissolved nutrients that could be used by actively growing plants and left behind in soil solution after the rainy season [33]. Furthermore, Brachiaria spp. association with $\mathrm{N}_{2}$ fixing bacteria could supply additional $\mathrm{N}$. 
Biological N fixation capacity for Brachiaria spp. grasses has been identified using ${ }^{15} \mathrm{~N}$ labeling and could supply as much as 20 to $40 \%$ of total $\mathrm{N}$ uptake (30 to $40 \mathrm{~kg} \mathrm{~N} /$ ha per $\mathrm{yr}$ ) $[34,35]$. A more minor contributor of $\mathrm{N}$ is OM. A hectare furrow slice $(17 \mathrm{~cm}$ deep) contains $2,240,702 \mathrm{~kg}$ soil and approximately $11 \mathrm{mg} / \mathrm{kg}$ organic-bound N. Approximately $25 \mathrm{~kg} \mathrm{~N} /$ ha per yr could be released from topsoil $\mathrm{OM}$ in this study, a small amount compared to the $330 \mathrm{~kg} \mathrm{~N} / \mathrm{ha}$ per yr in average crop removal across plots. Atmospheric $\mathrm{N}$ deposition could make a small additional contribution on a seasonal basis, perhaps as high as 10 to $15 \mathrm{~kg}$ N/ha per yr [36]. Magnitude, and in some cases existence, of these additional contributions is unknown but could explain relatively high Mulato II yields despite negative partial nutrient balances.

Partial nutrient balances calculated in this experiment did not account for potential nutrient losses that could make balances even more negative. Leaching losses can occur where compost or urea is applied to sandy soils. Water-logged and flooded plots during the rainy season lend favorable conditions for denitrification losses. High rainfall conditions in sandy soils may induce an annual "reset" of nutrients in soil solution, potentially inhibiting treatment response potential in this experiment. Surface applications of urea and compost (as done in experiment year one) furthermore favor losses from volatilization and runoff.

Nitrogen recovery was poor for compost application without urea primarily due to relatively low yields for compost-amended plots. In general, $\mathrm{N}$ recoveries were better for higher combined rates of compost and urea. In sandy, nutrient-depleted Zimbabwean soils, similar low $\mathrm{N}$ recovery was reported for compost (4\% recovery rate) applied to corn at $17 \mathrm{Mg} \mathrm{DM} /$ ha per yr (7.8 g N/kg DM) [37]. In the study in Zimbabwe, compost combined with $40 \mathrm{~kg} \mathrm{~N} / \mathrm{ha}$ per yr ammonium nitrate top-dressed to corn increased $\mathrm{N}$ recovery to $8 \%$. Chikowo et al. [37] concluded that low quality composted cattle manure could not supply adequate $\mathrm{N}$ and that most $\mathrm{N}$ needs would need to be fulfilled by mineral $\mathrm{N}$. Similar relatively low $\mathrm{N}$ recoveries were reported by Lynch et al. [38] for perennial forage production with composted dairy manure applied at 12.8 and $25.6 \mathrm{Mg} \mathrm{DM} /$ ha per yr in a temperate system ( $8.9 \%$ to $15.1 \%$ recovery). These studies are consistent with our findings that compost is not able to supply sufficient $\mathrm{N}$ for forage growth and that $\mathrm{N}$ recoveries improve when compost is applied together with inorganic $\mathrm{N}$.

\section{Conclusions}

Field experiment results suggest that the ability to sustain soil fertility over time in sandy tropical soils is dependent on the interaction between existing soil fertility and soil organic and inorganic amendments. Negative partial nutrient balances for $\mathrm{N}, \mathrm{P}$, and $\mathrm{K}$ indicate that, for the compost and urea application rates used in this experiment with actively growing forage grass, soil degradation is occurring and yields are unlikely to be sustainable over time. Overall, compost plays a potentially important role in maintaining $\mathrm{OM}$, preventing acidification, and supplying key macro- and micronutrients for plant uptake. Urea supplies readily available $\mathrm{N}$, which the grass could benefit from once other nutrient limitations had been overcome (with compost application). More broadly, these results suggest that extremely high rates of nutrient additions are required to realize the high yield potential in tropical forage systems. The consequences of high required nutrient inputs have important implications for intensification of smallholder crop-livestock systems and resulting nutrient loss potential.

\section{Appendix}

\section{Complementary Soil Fertility Data}

See Tables 8, 9, and 10.

\section{Conflict of Interests}

The authors declare that there is no conflict of interests regarding the publication of this paper.

\section{Acknowledgments}

The authors thank Françoise Vermeylen in the Cornell Statistical Consulting Unit for assistance with development of statistical models and Dr. J. H. Cherney for assistance with study design, planning, and implementation. They thank a team of institutions and individuals for supporting the experiment in Vietnam including farmers in Cát Trinh Commune, Hoang Văn Tùng at Research and Development Centre for Animal Husbandry in the Central Region, Nguyễn Văn Mười at Cát Trinh Commune, Nguyễn Tiên Thinh at Hue University of Agriculture and Forestry, and students at Hue University of Agriculture and Forestry. They acknowledge Dr. Nguyễn Hữu Văn at Hue University of Agriculture and Forestry and Jeff Corfield at Corfield Consultants for assistance with experiment design and insights about forage production systems in the experiment region. This field experiment was partially supported by an array of funding sources: Fulbright-Hays Doctoral Dissertation Research Abroad Fellowship, Richard Bradfield Research Awards, Cornell University Graduate School Travel Grants, Mario Einaudi Center for International Studies International Research Travel Grants, Gerald O. Mott Scholarship for Meritorious Graduate Students in Crop Science, Andrew W. Mellon Awards, Wilson G. Pond International Travel Award, and Clinton-Dewitt-Smith Fellowship. U.S. Department of Education Foreign Language and Area Studies Fellowships permitted acquisition of Vietnamese language proficiency, which was important to experiment participation, communication, and relationships with experiment participants.

\section{References}

[1] D. Parsons, P. A. Lane, L. D. Ngoan et al., "Systems of cattle production in South Central Coastal Vietnam," Livestock Research for Rural Development, vol. 25, article 25, 2013.

[2] N. X. Ba, P. A. Lane, D. Parsons et al., "Forages improve livelihoods of smallholder farmers with beef cattle in South Central 
Coastal Vietnam," Tropical Grasslands-Forrajes Tropicales, vol. 1, no. 2, 2013.

[3] W. Stür, T. T. Khanh, and A. Duncan, "Transformation of smallholder beef cattle production in Vietnam," International Journal of Agricultural Sustainability, vol. 11, no. 4, pp. 363-381, 2013.

[4] N. X. Ba, N. H. Van, J. Scandrett et al., "Improved forage varieties for smallholder cattle farmers in South Central Coastal Vietnam," Livestock Research for Rural Development, vol. 26, article 158, 2014.

[5] H. L. P. Khanh, N. X. Ba, N. H. Van et al., "Influence of labour saving in uptake of improved forage technologies by smallholder farmers in south central Vietnam," in Proceedings of the 16th AAAP Animal Science Congress, pp. 1126-1129, Jogjakarta, Indonesia, November 2014.

[6] F. Holmann, L. Rivas, P. Argel, and E. Pérez, "Impact of the adoption of Brachiaria grasses: Central America and Mexico," Livestock Research for Rural Development, vol. 16, article 98, 2004.

[7] W. W. Stür, P. M. Horne, F. A. Gabunada Jr., P. Phengsavanh, and P. C. Kerridge, "Forage options for smallholder cropanimal systems in Southeast Asia: working with farmers to find solutions," Agricultural Systems, vol. 71, no. 1-2, pp. 75-98, 2002.

[8] H. T. T. Hoa, P. T. Cong, H. M. Tam, W. Chen, and R. Bell, "Sandy soils in South Central Coastal Vietnam: their origin, constraints and management," in Proceedings of the 19th World Congress of Soil Science, Soil Solutions for a Changing World, Brisbane, Australia, August 2010.

[9] C. Neve, P.-Y. Ancion, H. H. T. Thai, T. P. Khanh, C. N. Chiang, and J. E. Dufey, "Fertilization capacity of aquatic plants used as soil amendments in the coastal sandy area of Central Vietnam," Communications in Soil Science and Plant Analysis, vol. 40, no. 17-18, pp. 2658-2672, 2009.

[10] C. Devendra, "Crop-animal systems in Asia: implications for research," Agricultural Systems, vol. 71, no. 1-2, pp. 169-177, 2002.

[11] C. A. Palm, R. J. Myers, and S. M. Nandwa, "Combined use of organic and inorganic nutrient sources for soil fertility maintenance and replenishment," in Replenishing Soil Fertility in Africa, R. Buresh, P. Sanchez and, and F. Calhoun, Eds., pp. 193-217, 1997.

[12] S. Zingore, R. J. Delve, J. Nyamangara, and K. E. Giller, "Multiple benefits of manure: the key to maintenance of soil fertility and restoration of depleted sandy soils on African smallholder farms," Nutrient Cycling in Agroecosystems, vol. 80, no. 3, pp. 267-282, 2008.

[13] S. Goyal, K. Chander, M. C. Mundra, and K. K. Kapoor, "Influence of inorganic fertilizers and organic amendments on soil organic matter and soil microbial properties under tropical conditions," Biology and Fertility of Soils, vol. 29, no. 2, pp. 196200, 1999.

[14] K. Kaur, K. K. Kapoor, and A. P. Gupta, "Impact of organic manures with and without mineral fertilizers on soil chemical and biological properties under tropical conditions," Journal of Plant Nutrition and Soil Science, vol. 168, no. 1, pp. 117-122, 2005.

[15] D. Ross, "Recommended soil tests for determining exchange capacity," in Recommended Soil Testing Procedures for the Northeastern United States. Northeastern Regional Bulletin \#493, J. Sims and A. Wolf, Eds., pp. 62-69, Agricultural Experiment Station, University of Delaware, Newark, Del, USA, 1995.

[16] E. Schulte and B. Hopkins, "Estimation of organic matter by weight loss-on-ignition," in Soil Organic Matter: Analysis and Interpretation, F. Magdoff, M. Tabatabai, and E. Hanlon, Eds., pp. 21-31, Soil Science Society of America, 1996.
[17] A. Mehlich, "Mehlich 3 soil test extractant: a modification of Mehlich 2 extractant," Communications in Soil Science and Plant Analysis, vol. 15, no. 12, pp. 1409-1416, 1984.

[18] J. B. Peters, S. Combs, B. Hoskins et al., Recommended Methods of Manure Analysis, University of Wisconsin Cooperative Extension, 2003.

[19] D. W. Pribyl, "A critical review of the conventional SOC to SOM conversion factor," Geoderma, vol. 156, no. 3-4, pp. 75-83, 2010.

[20] W. E. Jokela and G. W. Randall, "Fate of fertilizer nitrogen as affected by time and rate of application on corn," Soil Science Society of America Journal, vol. 61, no. 6, pp. 1695-1703, 1997.

[21] IUSS Working Group WRB, "World reference base for soil resources 2014: international soil classification system for naming soils and creating legends for soil maps," World Soil Resources Reports 106, FAO, Rome, Italy, 2014.

[22] H. T. T. Hoa, Survey Report for Soils Component 2, Australian Centre for International Agricultural Development, 2009.

[23] E. McLean, "Soil pH and lime requirement," in Methods of Soil Analysis. Part 2-Chemical and Microbiological Properties, A. L. Page, R. H. Miller, and D. R. Keeney, Eds., pp. 199-224, Soil Science Society of America, 2nd edition, 1982.

[24] W. Dahnke and G. Johnson, "Testing soils for available nitrogen," in Soil Testing and Plant Analysis, R. Westerman, Ed., pp. 127-140, Soil Science Society of America, 3rd edition, 1990.

[25] G. C. Marten, J. Shenk, and F. Barton, Near Infrared Reflectance Spectroscopy (NIRS): Analysis of Forage Quality, vol. 643 of Agricultural Handbook, United States Department of Agriculture, Agricultural Research Service, 1989.

[26] G. Griffin, D. Jokela, D. Ross, D. Pettrinelli, T. Morris, and A. Wolf, "Recommended soil nitrate tests," in Recommended Soil Testing Procedures for the Northeastern United States, J. Sims and A. Wolf, Eds., Northeastern Regional Publication No. 493, University of Delaware Agricultural Experiment Station, 2nd edition, 1995.

[27] SAS Institute, SAS for Windows. V. 9.3, SAS Institute, Cary, NC, USA, 2011.

[28] G. Kidder, C. Chambliss, and R. Mylavarapu, "UF/IFAS standardized fertilization recommendations for agronomic crops," Fact Sheet SL-129, University of Florida Cooperative Extension Service, Gainesville, Fla, USA, 2002.

[29] D. Beegle, "Soil fertility management," in The Penn State Agronomy Guide 2013-2014, A. Kirsten, Ed., Pennsylvania State University, State College, Pa, USA, 2013.

[30] J. H. Cherney, D. J. R. Cherney, and T. W. Bruulesma, "Potassium management," in Grass for Dairy Cattle, J. H. Cherney and D. J. R. Cherney, Eds., pp. 137-160, CAB International, 1998.

[31] R. M. Boddey, R. MacEdo, R. M. Tarré et al., "Nitrogen cycling in Brachiaria pastures: the key to understanding the process of pasture decline," Agriculture, Ecosystems \& Environment, vol. 103, no. 2, pp. 389-403, 2004.

[32] E. Amézquita, R. J. Thomas, I. M. Rao, D. L. Molina, and P. Hoyos, "Use of deep-rooted tropical pastures to build-up an arable layer through improved soil properties of an Oxisol in the Eastern Plains (Llanos Orientales) of Colombia," Agriculture, Ecosystems \& Environment, vol. 103, no. 2, pp. 269-277, 2004.

[33] F. N. Ponnamperuma, "Effects of flooding on soils," in Flooding and Plant Growth, T. T. Kozlowski, Ed., Academic Press, Cambridge, Mass, USA, 1984.

[34] V. Reis, F. dos Reis Jr., D. Quesada et al., "Biological nitrogen fixation associated with tropical pasture grasses," Australian Journal of Plant Physiology, vol. 28, pp. 837-844, 2001. 
[35] R. M. Boddey and R. L. Victoria, "Estimation of biological nitrogen fixation associated with Brachiaria and Paspalum grasses using ${ }^{15} \mathrm{~N}$ labelled organic matter and fertilizer," Plant and Soil, vol. 90, no. 1, pp. 265-292, 1986.

[36] B. Eickhout, A. F. Bouwman, and H. Van Zeijts, "The role of nitrogen in world food production and environmental sustainability," Agriculture, Ecosystems \& Environment, vol. 116, no. 1-2, pp. 4-14, 2006.

[37] R. Chikowo, P. Mapfumo, P. Nyamugafata, and K. E. Giller, "Maize productivity and mineral N dynamics following different soil fertility management practices on a depleted sandy soil in Zimbabwe," Agriculture, Ecosystems \& Environment, vol. 102, no. 2, pp. 119-131, 2004.

[38] D. H. Lynch, R. P. Voroney, and P. R. Warman, "Nitrogen availability from composts for humid region perennial grass and legume-grass forage production," Journal of Environmental Quality, vol.33, no. 4, pp. 1509-1520, 2004. 


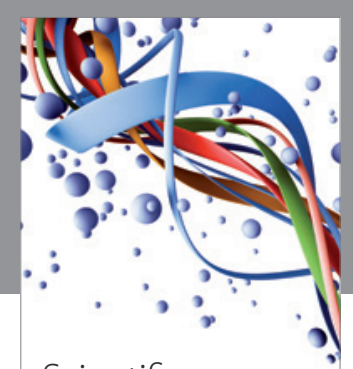

Scientifica
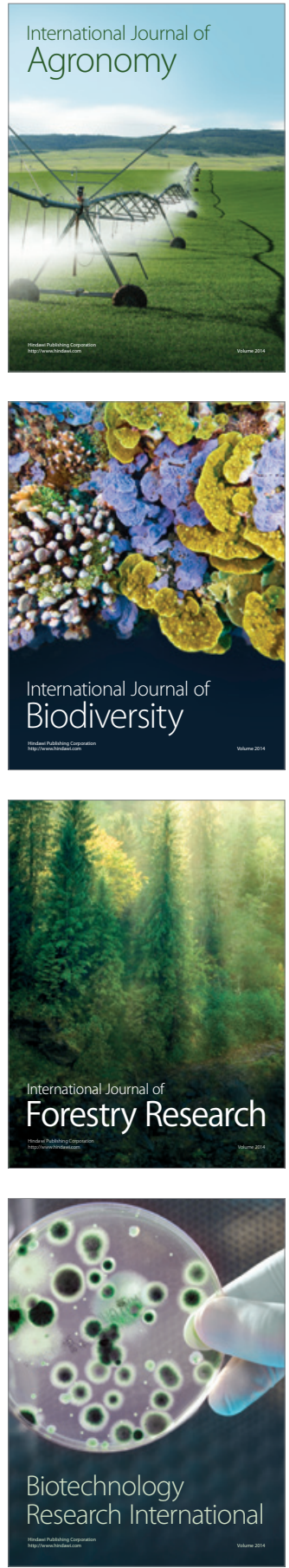
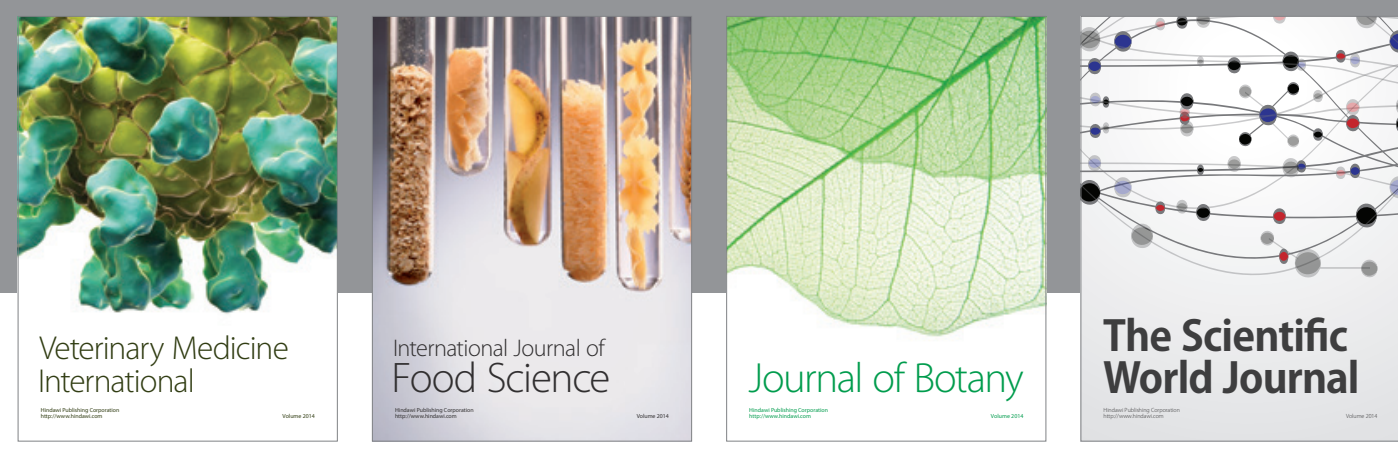

The Scientific

\section{World Journal}

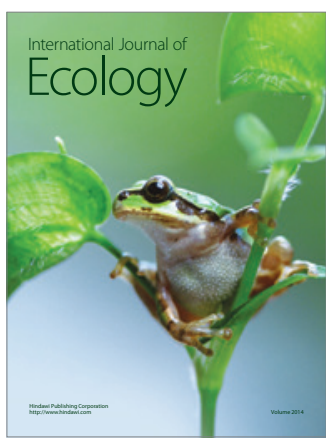

\section{Hindawi}

Submit your manuscripts at

http://www.hindawi.com
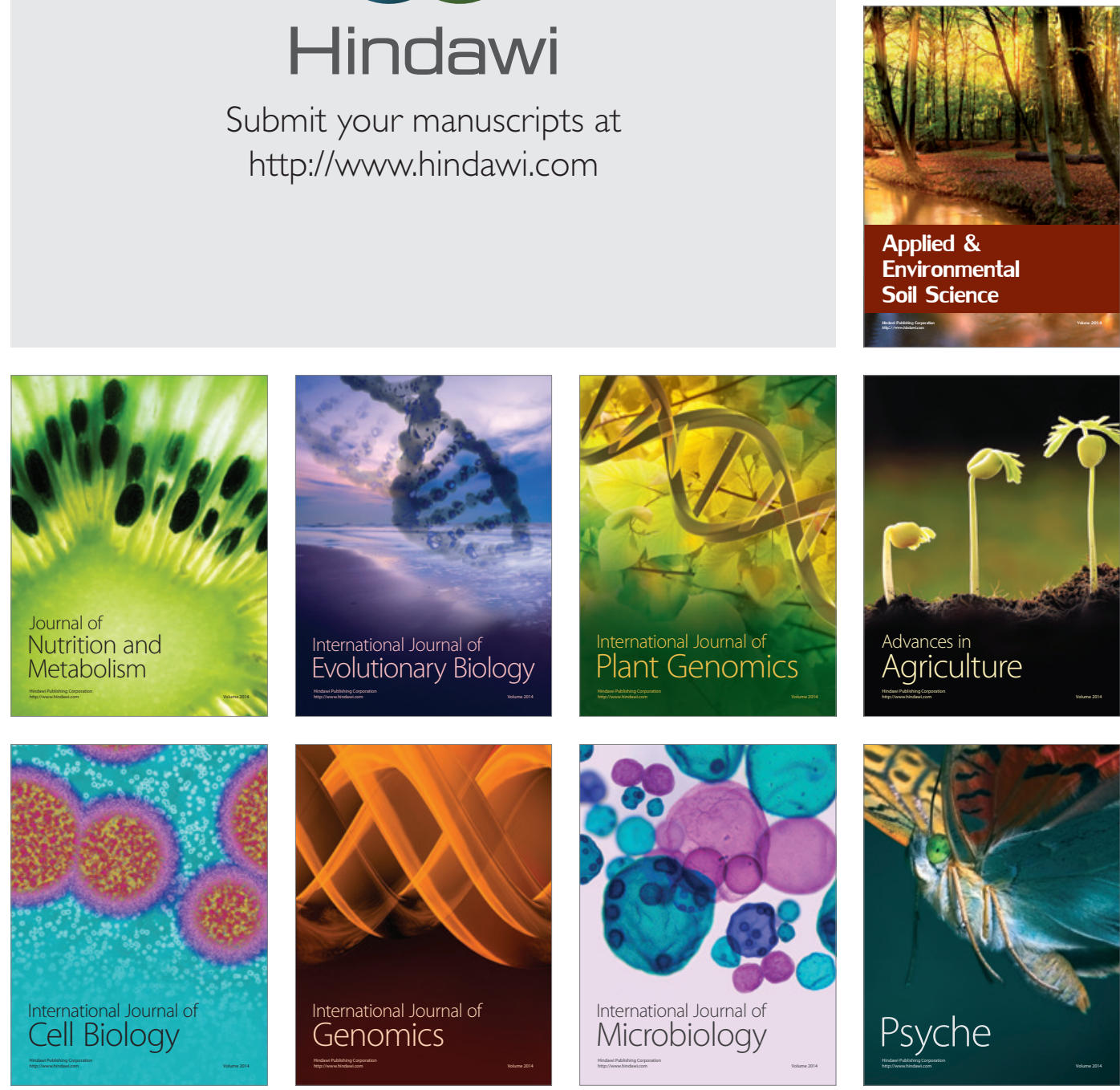
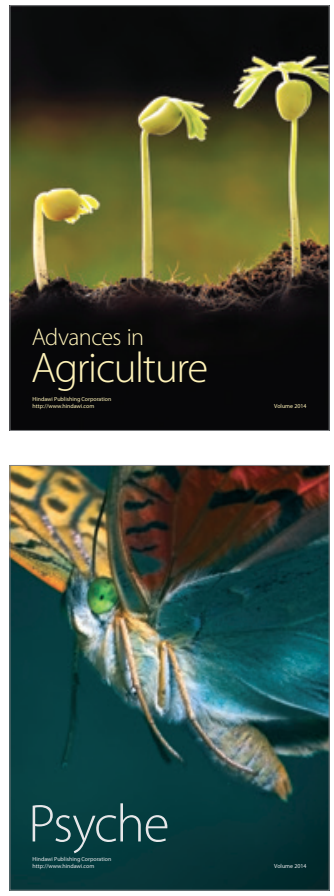